\title{
KARAKTERISTIK MORFOLOGI SPORA TUMBUHAN PAKU (PTERIDOPHYTA) PADA KELAS FILICINAE (PAKU SEJATI) DI GUNUNG TANGGAMUS, LAMPUNG
}

\section{Skripsi}

Diajukan Untuk Memenuhi Tugas-Tugas dan Memenuhi Syarat-Syarat Guna Mendapatkan Gelar Sarjana Pendidikan (S.Pd) dalam Ilmu Tarbiyah

Oleh

INGGIT DWI KARIMAH

NPM. 1611060160

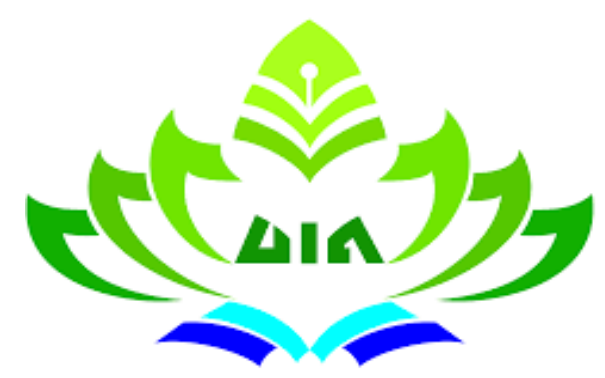

FAKULTAS TARBIYAH DAN KEGURUAN UNIVERSITAS ISLAM NEGERI RADEN INTAN

LAMPUNG

$1441 \mathrm{H} / 2020 \mathrm{M}$ 


\section{KARAKTERISTIK MORFOLOGI SPORA TUMBUHAN PAKU (PTERIDOPHYTA) PADA KELAS FILICINAE (PAKU SEJATI) DI GUNUNG TANGGAMUS, LAMPUNG}

\section{Skripsi}

Diajukan Untuk Memenuhi Tugas-Tugas dan Memenuhi Syarat-Syarat Guna Mendapatkan Gelar Sarjana Pendidikan (S.Pd) dalam Ilmu Tarbiyah

\section{Oleh}

INGGIT DWI KARIMAH

NPM. 1611060160

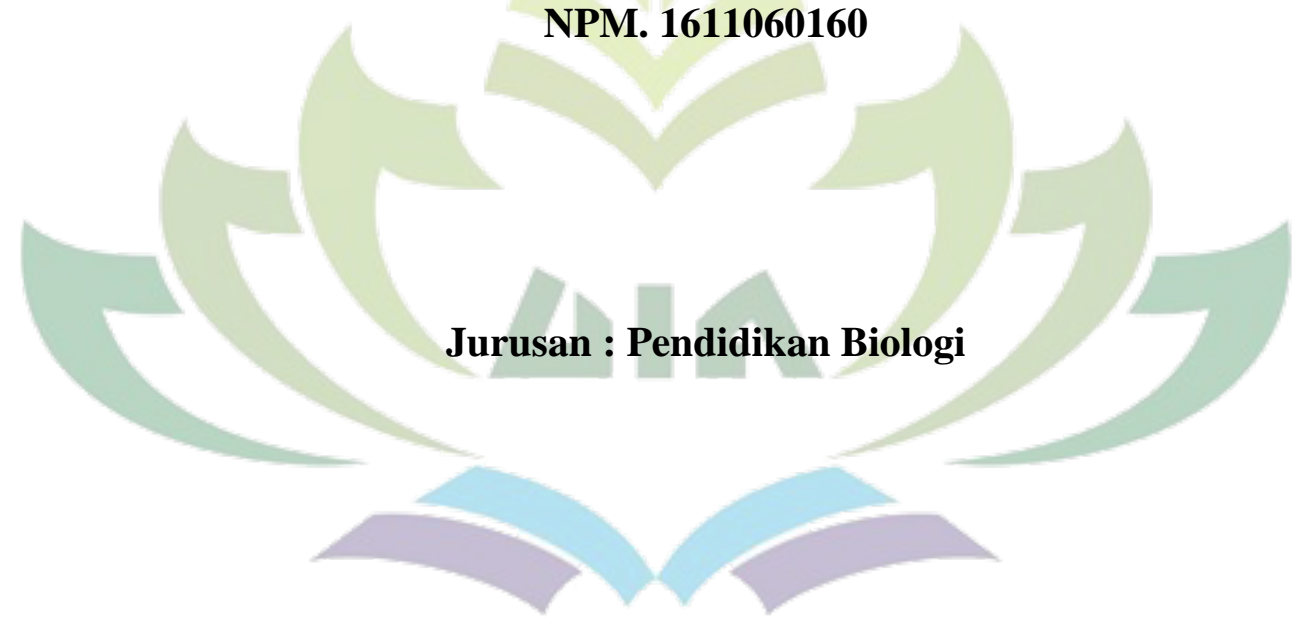

Pembimbing I : Dwijowati Asih Saputri, M.Si

Pembimbing II : Ovi Prasetya Winandari, M.Si

FAKULTAS TARBIYAH DAN KEGURUAN

UNIVERSITAS ISLAM NEGERI RADEN INTAN

LAMPUNG

1441 H / 2020 M 


\begin{abstract}
ABSTRAK
KARAKTERISTIK MORFOLOGI SPORA TUMBUHAN PAKU (PTERIDOPHYTA) PADA KELAS FILICINAE (PAKU SEJATI) DI GUNUNG TANGGAMUS, LAMPUNG
\end{abstract}

\author{
Oleh: \\ Inggit Dwi Karimah
}

\begin{abstract}
Tumbuhan paku merupakan tumbuhan peralihan. Spora berfungsi sebagai alat perkembangbiakan dalam regenerasi. Spora memiliki lapisan pelindung, yang terbagi menjadi dua yaitu lapisan luar (eksin) dan lapisan dalam (intin). Penelitian ini dilakukan untuk mengetahui perbedaan spora tumbuhan paku pada kelas Filicinae dengan memperhatikan bentuk, warna, letak persebaran sorus, tipe apertura dan ukuran spora spora tumbuhan paku di Gunung Tanggamus, Lampung. Metode penelitian yang di gunakan pada penelitian ini yaitu survei eksploratif dan menggunakan 9 titik plot. Pengambilan sampel tumbuhan dilakukan dengan melihat permukaan bawah daun yang sudah terdapat sorus, selanjutnya sampel akan di bawa ke Laboratorium Terpadu UIN Raden Intan Lampung untuk dilihat karakteristik sporanya menggunakan mikroskop.
\end{abstract}

Kata kunci : Karakteristik spora, Tumbuhan paku, Kelas Filicinae, Gunung Tanggamus. 


\section{SURAT PERNYATAAN}

Saya yang bertanda tangan di bawah ini :

$\begin{array}{ll}\text { Nama } & : \text { Inggit Dwi Karimah } \\ \text { NPM } & : 1611060160 \\ \text { Jurusan / Prodi } & : \text { Pendidikan Biologi } \\ \text { Fakultas } & : \text { Tarbiyah dan Keguruan }\end{array}$

Menyatakan bahwa skripsi yang berjudul "Karakteristik Morfologi Spora Tumbuhan Paku (Pteridophyta) pada Kelas Filicinae (Paku Sejati) di Gunung Tanggamus, Lampung" adalah benar-benar merupakan hasil karya penyusunan sendiri, bukan duplikasi atau saduran dari karya orang lain kecuali pada bagian yang telah di rujuk dan di sebutkan di footnote atau daftar pustaka. Apabila di lain waktu terbukti adanya penyimpangan dalam karya ini, maka tanggung jawab sepenuhnya ada pada penulis.

Demikian surat pernyataan ini saya buat agar dapat di maklumi.

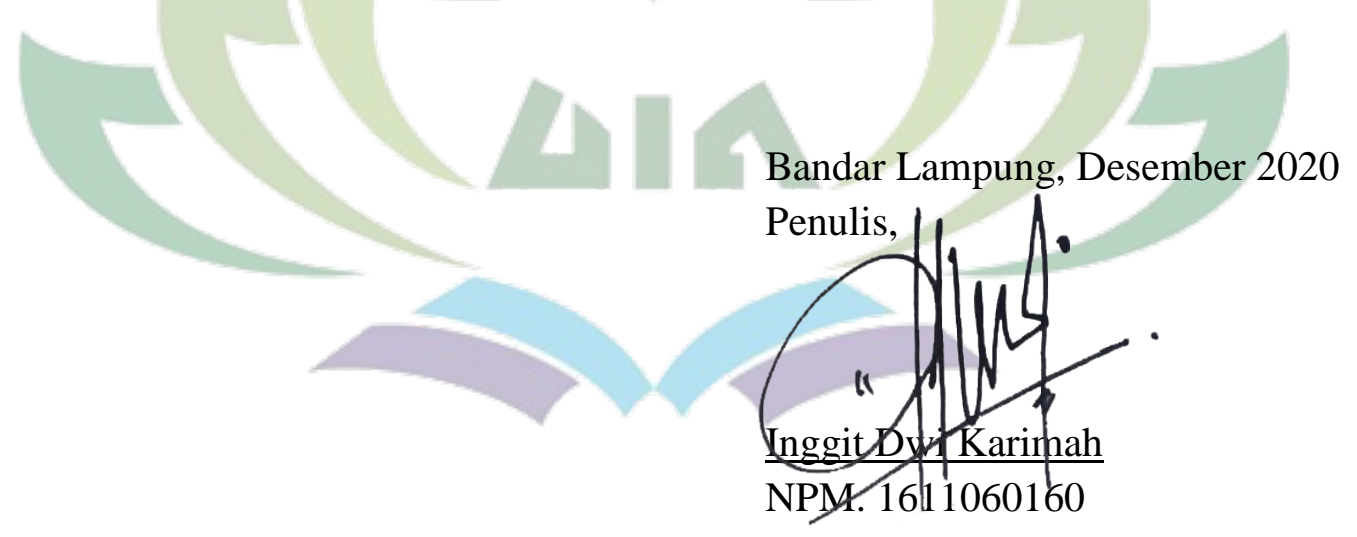


Alamat : J. Letkol H. EndroSuratminSukarame Bandar Lampung Telp. 0721780887

\section{PERSETUJUAN}

Judul Skripsi : KARAKTERISTK MORFOLOGI SPORA TUMBUHAN PAKU (PTERIDOPHYTA) PADA KELAS FILICINAE (PAKU SEJATI) DI GUNUNG TANGGAMUS, LAMPUNG

Nama

NPM EN INT: 1611060160

Jurusan : Pendidikan Biologi

Fakultas NT/: Tarbiyah dan Keguruan

\section{MENYETUJUI}

Untuk di munaqasyahkan dan di pertahankan dalam Sidang Munaqasyah Fakultas Tarbiyah dan Keguruan UIN Raden Intan Lampung

Pembimbing I

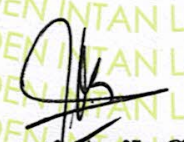

Dwiiowati Asih Saputri, M.Si

NIP. 197202111999032002

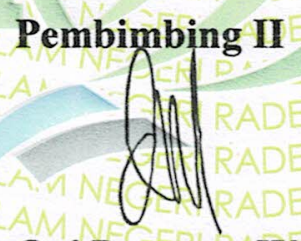

Ovi Prasetya Winandari, M.Si NIP.-

Mengetahui

Ketua Jurusan Pendigdikan Biologi

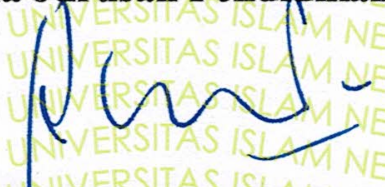

Dr. Eko Kuswanto, M.Si

NIP. 197505142008011009 
KEMENTERIAN AGAMA

UNIVERSITAS ISLAM NEGERI RADEN INTAN LAMPUNG

FAKULTAS TARBIYAH DAN KEGURUAN

Alamat:J1. Letko1H. EndroSuratminSukarameBandarLampungTe1p. (0721)703260

\section{PENGESAHAN}

Skripsi dengan judul "KARAKTERISTIK MORFOLOGI SPORA TUMBUHAN PAKU (PTERIDOPHYTA) PADA KELAS FILICINAE (PAKU SEJATI) DI GUNUNG TANGGAMUS, LAMPUNG" disusun oleh: INGGIT DWI KARIMAH, NPM. 1611060160, Jurusan Pendidikan Biologi telah diujikan pada sidang munaqosyah pada hari/tanggal: Jum'at, 18 Desember 2020 pukul 08.00 s.d 09.30WIB.

TIM DEWAN PENGUJI

Ketua

: Dr. Eko Kuswanto, M.Si

Sekretaris

: Aulia UImilah, M.Sc.

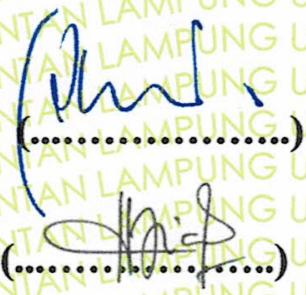

Penguji Utama

: Nurhaida Widiani, M.Biotech.

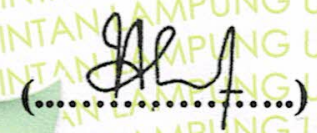

Penguji Pendamping I : Dwijowati Asih Saputri, M.Si

Penguji Pendamping II : Ovi Prasetya Winandari, M. Si.

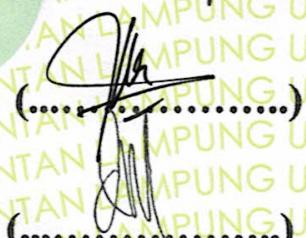

Mengetahui,

Dekan Fakultas Tarbiyah dan Keguruan

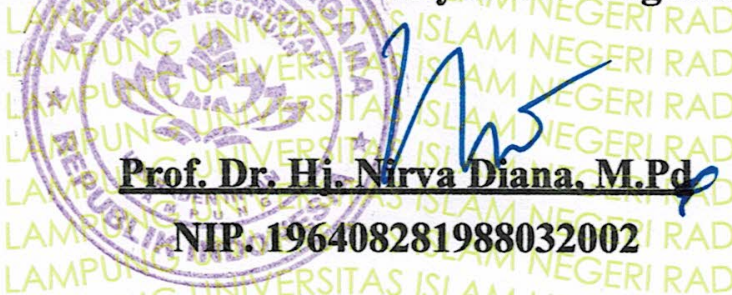




\section{MOTTO}

"Senyum manismu dihadapan saudaramu adalah shadaqoh."

(HR Thirmidzi)

"Ponsel dapat diisi daya saat baterainya habis, tetapi hidup tidak akan berulang. Cara terbaik untuk menjalani hidup tanpa penyesalan bukanlah dengan mengeluh dalam ketidakberdayaan. Akan tetapi dengan memahami setiap menit dan setiap detiknya." (Huang Renjun)

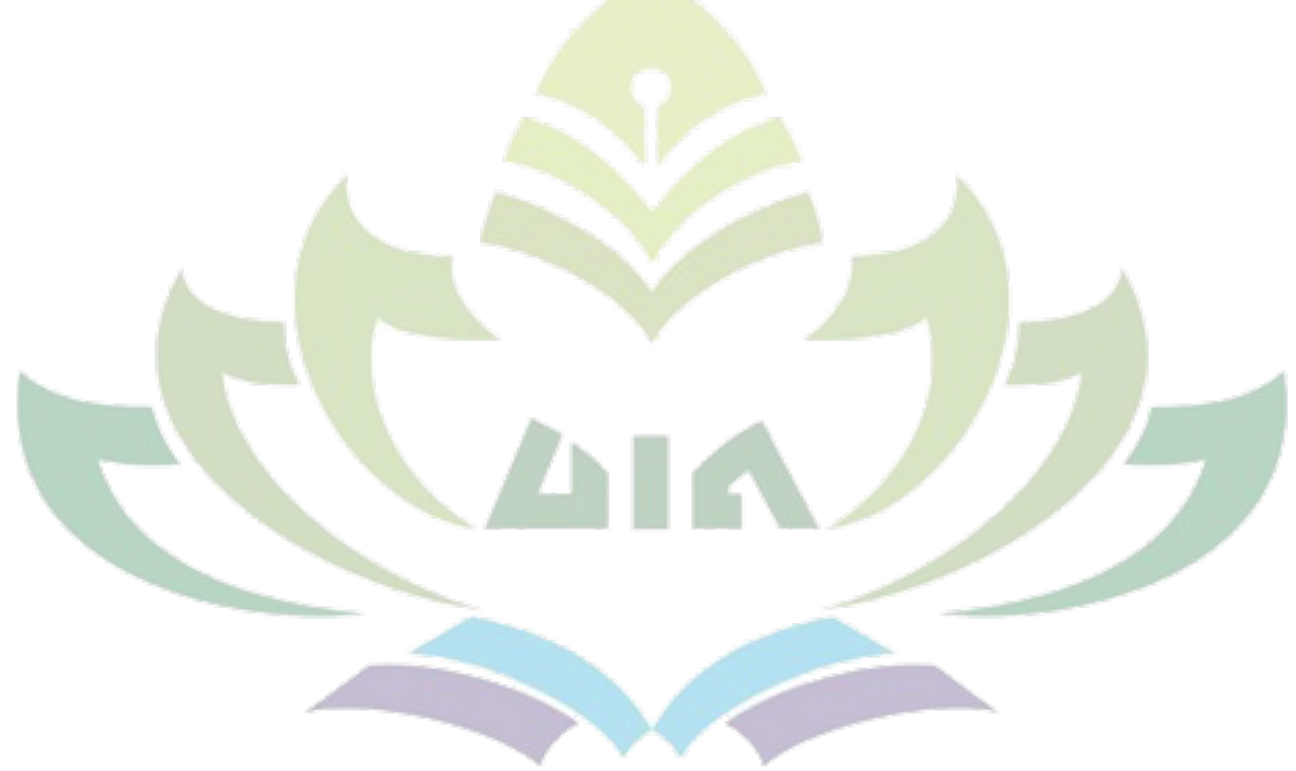




\section{PERSEMBAHAN}

Dengan mengucapkan kata syukur Alhamdulillah, saya ingin mempersembahkan karya saya untuk orang-orang yang saya sayangi :

1. Kepada orang tuaku tercinta Ayahanda Ngadimin dan Ibunda Karimi, sebagai motivator yang sangat berarti dalam hidupku yang tak pernah jemu dalam mendoakan dan menyemangatiku, dan semua pengorbanan kalian yang serta bimbingan kalian hingga dapat mengantarkan ku sampai saat ini.

2. Kepada kakak ku tersayang Ana Febrianti Wulandari yang telah membantu mendoakan, menyemangati, menemani dan menyayangiku dengan seperempat hatinya.

3. Kepada sahabatku tercinta Muhamad Firmansyah, Puji Nurrohmah, Selvira Rahmawati, Sukron Nasir, yang selalu ada dalam situasi apapun, membantu dalam segala urusan, memotivasi dan menyemangati dalam pembuatan skripsi ini, dan yang selalu mengingatku jika aku melakukan kesalahan.

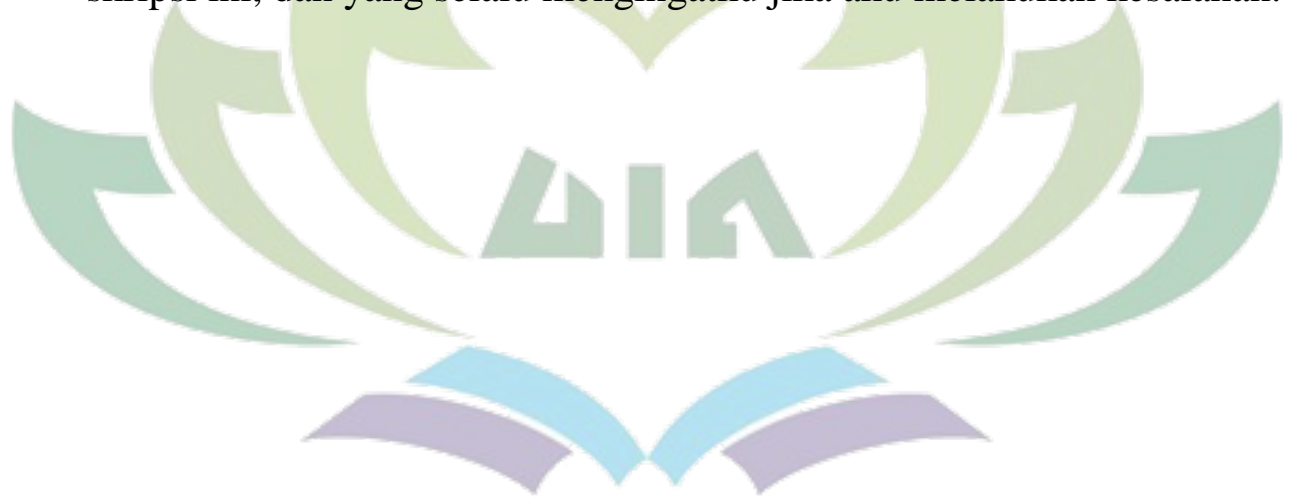




\section{DAFTAR RIWAYAT HIDUP}

Penulis bernama Inggit Dwi Karimah, Lahir di Candipuro, Lampung Selatan, 23 Januari 1999, penulis merupakan anak kedua dari pasangan Bapak Ngadimin dan Ibu Karimi, memiliki satu orang kakak perempuan bernama Ana Febrianti Wulandari.

Pendidikan formal penulis dimulai sejak pendidikan pertama di SDN Banyumas pada tahun 2004 lulus pada tahun 2010. Pada tahun yang sama penulis melanjutkan ke MTs Miftahul Ulum Candipuro lulus pada tahun 2013. Kemudian melanjutkan ke SMA Negeri 1 Sidomulyo, Lampung Selatan, tahun 2013 lulus pada tahun 2016. Selanjutnya penulis pada tahun 2016 terdaftar sebagai mahasiswi pendidikan biologi Fakultas Tarbiyah dan Keguruan di Universitas Islam Negeri Raden Intan Lampung.

Inggit Dwi Karimah menyelesaikan program S1 Pendidikan Biologi Fakultas Tarbiyah dan Keguruan di Universitas Islam Negeri Raden Intan Lampung pada tahun 2020. Fokus penelitian penulis yaitu pada karakteristik sorus dan spora tumbuhan paku kelas Filicinae di Gunung Tanggamus, yang di bimbing oleh Ibu Dwijowati Asih Saputri, M.Si (pembimbing 1) dan Ibu Ovi Prasetya Winandari, M.Si (pembimbing 2). 


\section{KATA PENGANTAR}

Alhamdulillah segala puji serta syukur bagi Allah SWT. yang telah memberikan rahmat dan hidayah-Nya berupa iman, ilmu, amal dan kesehatan, sehingga penulis dapat menyelesaikan skripsi yang berjudul "Karakteristik Morfologi Spora Tumbuhan Paku (Pteridophyta) Pada Kelas Filicinae (Paku Sejati) di Gunung Tanggamus, Lampung". Sholawat serta salam semoga senantiasa tercurahkan kepada junjungan dan suri tauladan kita Nabi Muhammad SAW., yang selalu memberi petunjuk dan senantiasa mengharapkan kebaikan bagi umatnya. Semoga kelak di hari akhir kita diakui sebagai umatnya dan mendapatkan syafaatnya. Aamiin.

Skripsi ini disusun sebagai tugas persyaratan untuk menyelesaikan studi program sastra 1 (S1) Fakultas Tarbiyah dan Keguruan UIN Raden Intan Lampung, guna memperoleh gelar Sarjana Pendidikan (S.Pd). terselesaikannya skripsi ini tidak terlepas dari bantuan dan dorongan dari berbagai pihak. Penulis mengucapkan terimakasih melalui tulisan ini kepada :

1. Prof. Dr. Hj. Nirva Diana, M.P.d selaku Dekan Fakultas Tarbiyah dan Keguruan UIN Raden Intan Lampung.

2. Dr. Eko Kuswanto, M.Si selaku Ketua Prodi Pendidikan Biologi.

3. Ibu Dwijowati Asih Saputri, M.Pd selaku pembimbing I, Ibu Ovi Prasetya Winandari, M.Pd yang telah dengan sabar membimbing dan memberikan motivasi serta arahan dalam menyelesaikan skripsi ini.

4. Serta terimakasih kepada seluruh pihak yang telah membantu penulis dalam menyelesaikan skipsi ini yang tidak dapat disebut satu persatu.

Semoga Allah melimpahkan rahmat dan Karunianya kepada kita semua. Penulis berharap skripsi ini dapat memberikan manfaat bagi kita semua.

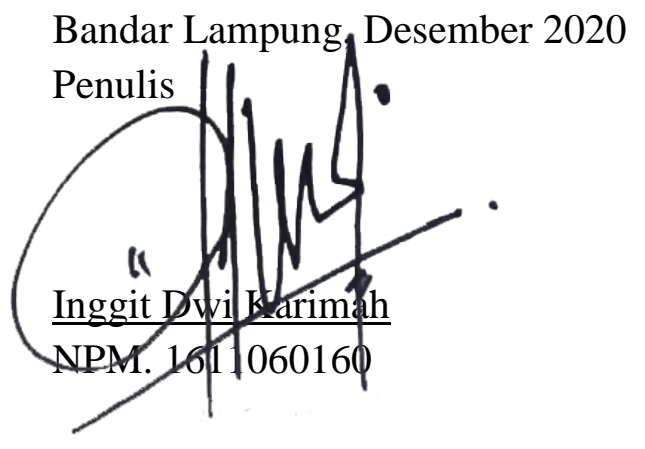




\section{DAFTAR ISI}

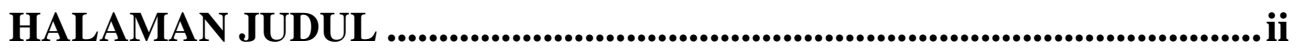

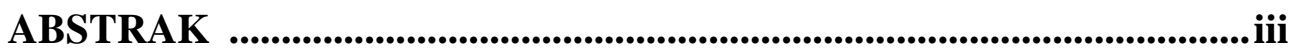

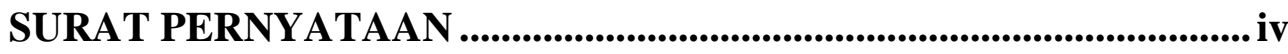

HALAMAN PERSETUJUAN ............................................................... v

HALAMAN PENGESAHAN ................................................................ vi

MOTTO ........................................................................................... vii

PERSEMBAHAN.......................................................................................... viii

DAFTAR RIWAYAT HIDUP ........................................................................ ix

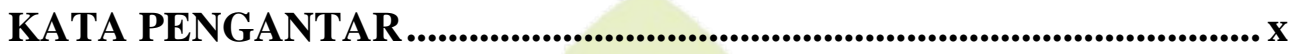

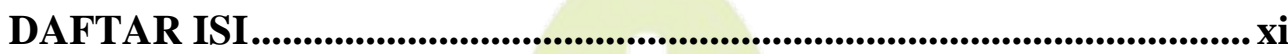

DAFTAR TABEL ..............................................................................

DAFTAR GAMBAR ...................................................................................... xiv

DAFTAR LAMPIRAN ..........................................................................

\section{BAB I PENDAHULUAN}

A. Penegasan Judul ...........................................................................1 1

B. Alasan Memilih Judul..................................................................3

C. Latar Belakang ........................................................................4

D. Identifikasi dan Batasan Masalah ................................................... 12

E. Rumusan Masalah...................................................................... 13

F. Tujuan Penelitian ............................................................................... 13

G. Manfaat Penelitian .............................................................................. 14

\section{BAB II LANDASAN TEORI DAN PENGAJUAN HIPOTESIS}
A. Pengertian Tumbuhan Paku ................................................... 15
B. Tempat Hidup Tumbuhan Paku …....................................... 16

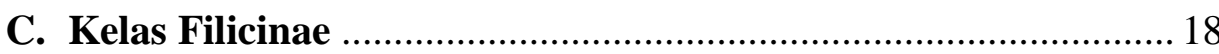
1. Anak Kelas Eusporangiatae ...................................................... 19
2. Anak Kelas Leptosporangiatae ............................................ 21

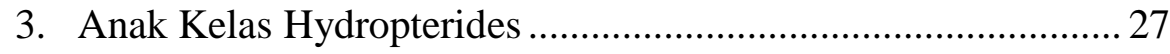
D. Daur Hidup (Metagenesis) ........................................................... 30
E. Morfologi Spora ................................................................................................ 31

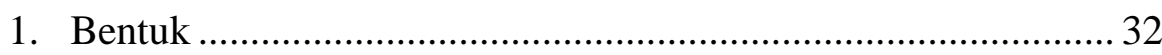

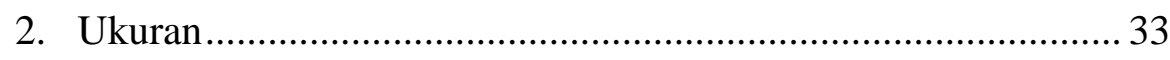

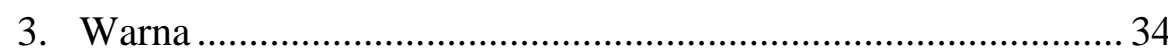

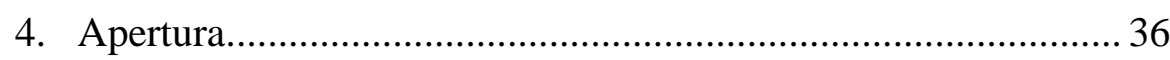




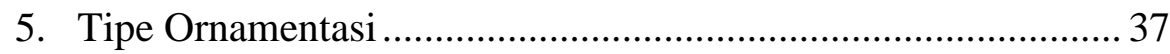

F. Manfaat Tumbuhan Paku (Pteridophyta) ................................... 38

\section{BAB III METODE PENELITIAN}

A. Waktu Dan Tempat Penelitian ......................................................... 39

B. Pendekatan Dan Jenis Penelitian.................................................. 40

C. Populasi, Sampel dan Teknik Pengumpulan Data...................... 41

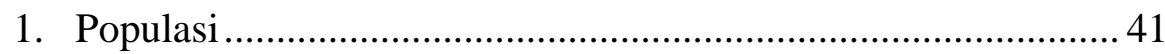

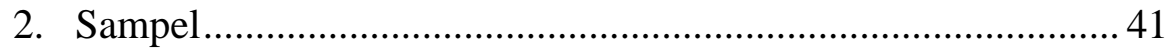

3. Teknik Pengumpulan Data....................................................... 41

D. Instrumen Penelitian.................................................................... 43

E. Teknik Analisis Data.......................................................................... 44

F. Alur Kerja Penelitian................................................................. 47

\section{BAB IV HASIL PENELITIAN DAN PEMBAHASAN}

A. Deskripsi Data ...................................................................... 48

B. Data Hasil Penelitian dan Analisis ...........................................56

C. Pembahasan Hasil Penelitian dan Analisis ..................................61 61

D. Faktor yang Mempengaruhi Pertumbuhan Tumbuhan Paku .. 83

\section{BAB V PENUTUP}

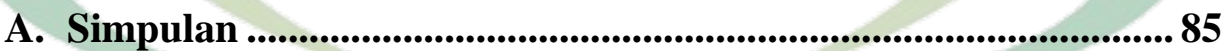

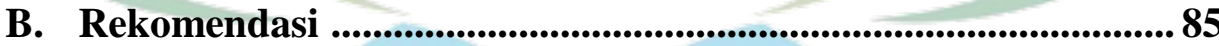

DAFTAR PUSTAKA

\section{LAMPIRAN}




\section{DAFTAR TABEL}

\section{Halaman}

Tabel 4.1 Data Spesies Tumbuhan Paku Untuk Masing-Masing

Plot/Petak. 48

Tabel 4.2 Data Kerapatan Spesies........................................................... 49

Tabel 4.3 Data Kerapatan Relatif ............................................................... 50

Tabel 4.4 Frekuensi Spesies dan Frekuensi Relatif ................................... 50

Tabe 4.5 Nilai Luas Penutupan Spesies dan Luas Penutupan Relatif........... 51

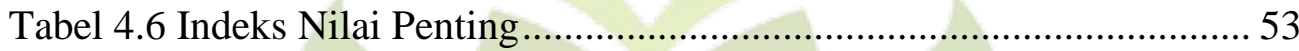

Tabel 4.7 Data Spesies Tumbuhan Paku Epifit.. ........................................ 54

Tabel 4.8 Faktor Yang Mempengaruhi Pertumbuhan Paku........................55

Tabel 4.9 Data Sorus Tumbuhan Paku Terestrial ...................................... 56

Tabel 4.10 Data Spora Tumbuhan Paku Terestrial .................................. 57

Tabel 4.11 Data Sorus Tumbuhan Paku Epifit... ....................................... 57

Tabel 4.12 Data Spora Tumbuhan Paku Epifit ......................................... 59 


\section{DAFTAR GAMBAR}

\section{Halaman}

Gambar 2.2.1 (a) Pohon Cyathea nilgirensis (b) Spora...........................22

Gambar 2.2.2 Pyrrosia angustata ..................................................... 24

Gambar 2.2.3 (a) Pohon Platycerium bifurcatum (b) Spora.......................2 25

Gambar 2.2 (a) Pohon Dynaria sp. $\quad$ (b) sorus .......................................26

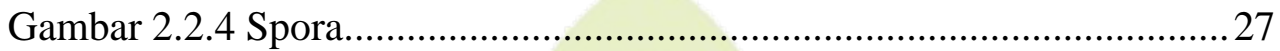

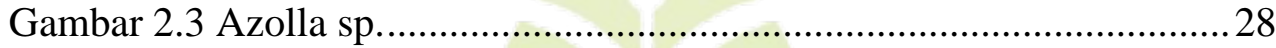

Gambar 2.4.1 Daur Hidup Pteridophyta .................................................. 31

Gambar 2.5.1 Bentuk-Bentuk Spora Tumbuhan Paku

A. Bulat, B. Tidak beraturan, C. Tidak beraturan, D. Elips,

E Segitiga dengan sisi cembung dan dua sisi cekung,

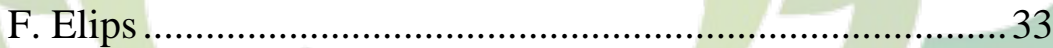

Gambar 2.5.2 Sorus Paku Sarang Burung............................................ 34

Gambar 2.5.3 Sorus Paku Rasam ...................................................... 34

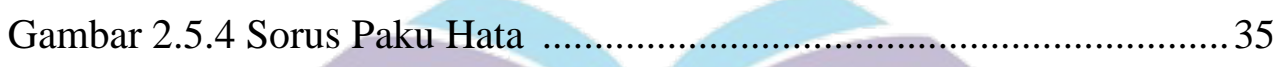

Gambar 2.5.5 Sorus Paku Pedang .......................................................... 35

Gambar 2.5.7. Tipe-Tipe Apertura Spora

A. Monocolpate, B. Syncolpate, C. Inaperturate, D.

Monocolpate, E. Inaperturate ................................................36

Gambar Peta 3.1 Lokasi Penelitian Gunung Tanggamus...........................39

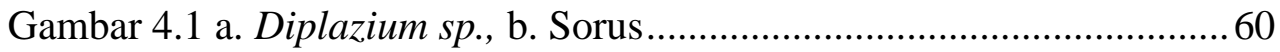

Gambar 4.2 a. Sorus perbesaran 10/0.25, b. Spora 10/0.25

Gambar 4.5, a. Diplazium dilatatum, b. Sorus ..........................................61

Gambar 4.6 a. Spora perbesaran 4/0.10, b. spora perbesaran

$10 / 0.25$ 
Gambar 4.7 a. Pteridium aquilinum, b.Sorus .63

Gambar 4.4 a. Spora perbesaran 4/0.10, b. Spora perbesaran $10 / 0.25$ 64

Gambar 4.9 a. Oleandra musifolia, b. Sorus 64

Gambar 4.10 a. Sorus perbesaran 4/0,10, b. Spora perbesaran 10/0,25 .....65

Gambar 4.13 a. Dipteris conjugata b. Sorus .66

Gambar 4.14 a. Sorus perbesaran 4/0.10, b. Sorus perbesaran 10/0.25, c. spora perbesaran $10 / 0.25$ 67

Gambar 4.15 a. Asplenium nidus, b. Sorus .68

Gambar 4.16 a. Sorus perbesaran 4/0.10, b. Spora perbesaran 10/0.25 69

Gambar 4.17 a. Asplenium salignum, b. Sorus .70

Gambar 4.18 a. Sorus perbesaran 4/0.10, b. perbesaran 10/0.25, c. spora perbesaran 10/0.25

Gambar 4.19 a. Phymatosorus sp., b. Sorus .72

Gambar 4.20a. Sorus perbesaran 4/0.10, b. Spora perbesaran 10/0.25 ......73

Gambar 4.21 a. Belvisia spicata, b. Sorus. .73

Gambar 4.22 a. Sorus perbesaran 4/0.10, b. Spora perbesaran 10/0.25, c. Spora yang terpisah 74

Gambar 4.23 a. Belvisia sp 2, b. Sorus 75

Gambar 4.24 a. sorus perbesaran 4/0.10, b. spora perbesaran $10 / 0.25$ 76

Gambar 4.25 a. Belvisia sp 1, b. Sorus 77

Gambar 4.25 a sori perbesaran 4/0.10, b. Spora perbesaran 10/0.25 ......... 78

Gambar 4.26 a. Vittaria longifolia, b. Sori 78

Gambar 4.27 a. Sori perbesaran 4/0.10, b. perbesaran 10/0.25 .79 
Gambar 4.28 a. Vittaria ensiformis, b. Daun V. ensiformis yang Terdapat Soris .80

Gambar 4.29 a. Sori perbesaaran 4/0.10, b perbesaran 10/0.25 81

Gambar 4.30 a. Pyrrosia rasamale, b. Sori 81

Gambar 4.31 a. Sori perbesaran 4/0.10, b. Spora perbesaran 10/0.25 ........82

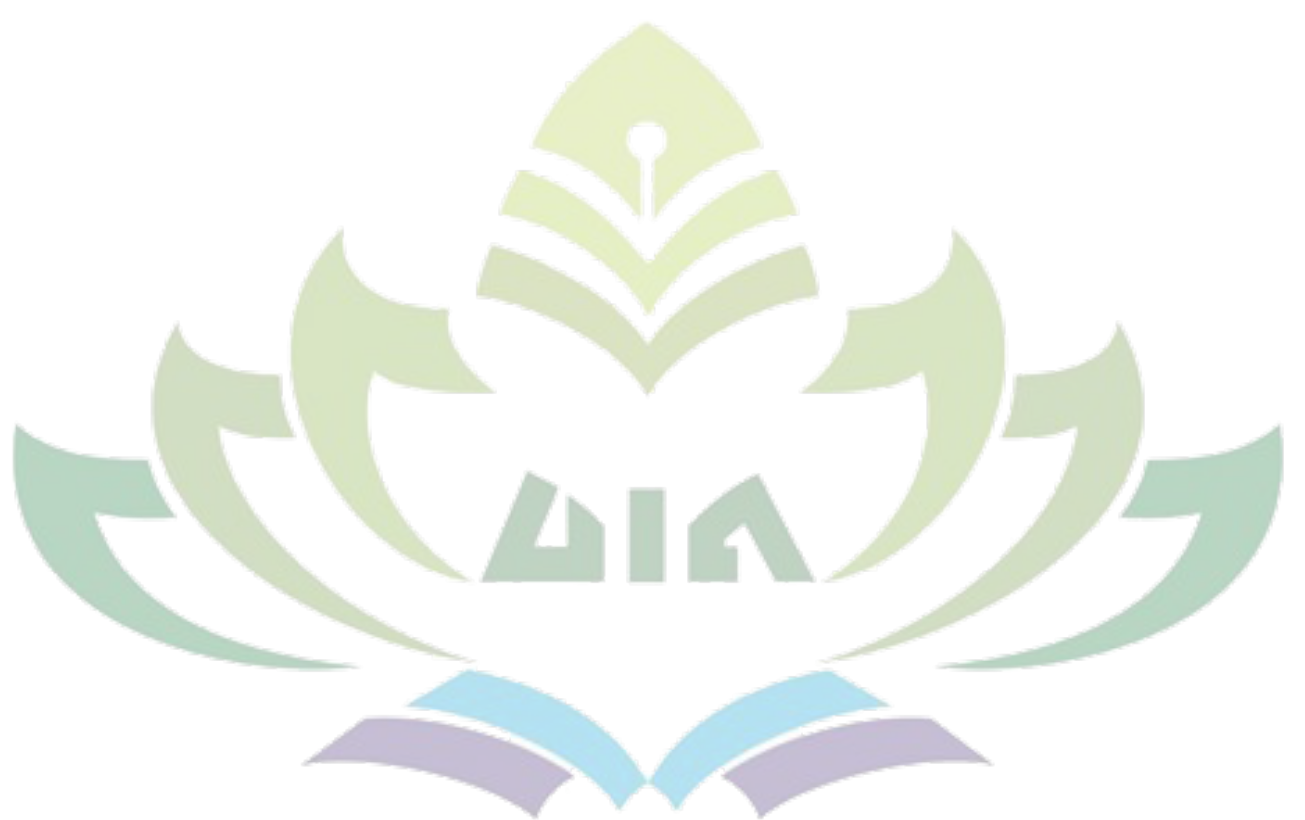




\section{DAFTAR LAMPIRAN}

LAMPIRAN I Pengamatan Sampel ......................................................... 90

LAMPIRAN II Pengamaan Sampel Tumbuhan Paku ................................... 96

LAMPIRAN III Perhitungan Kerapatan Spesies dan Kerapatan Relatif ......... 101

LAMPIRAN IV Roundown Kegiatan Gunung Tanggamus ........................ 111

LAMPIRAN V Dokumentasi.............................................................. 112

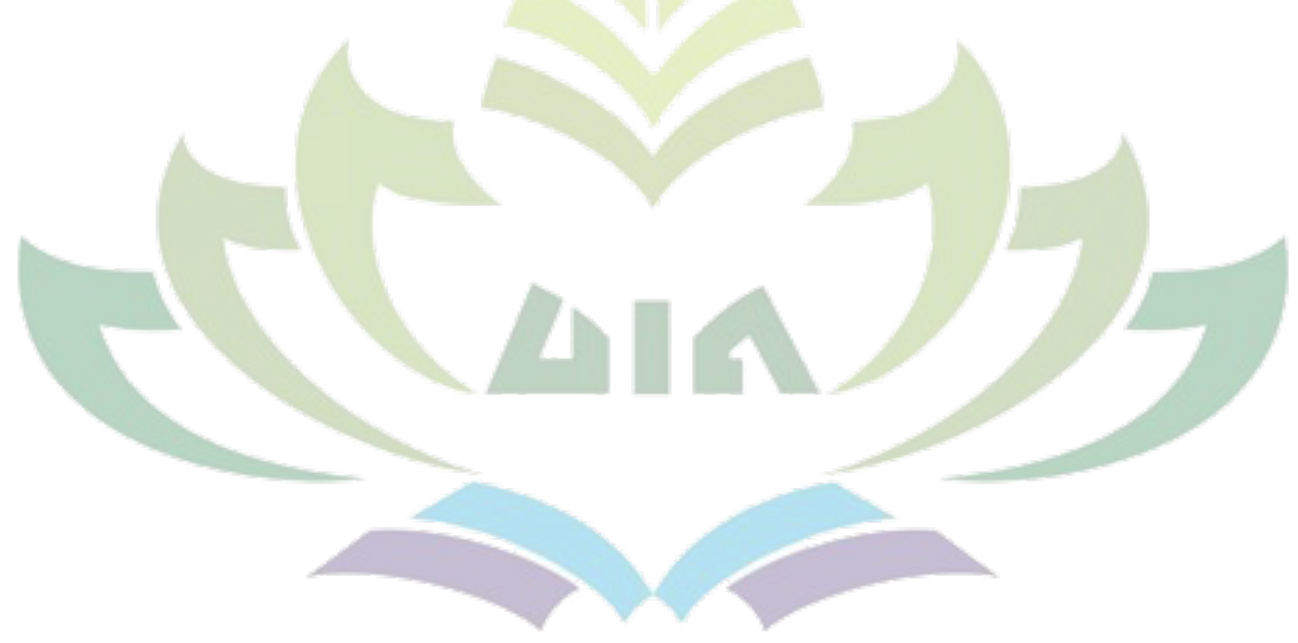




\section{BAB I}

\section{PENDAHULUAN}

\section{A. Penegasan Judul}

Penulisan karya ilmiah terdapat tatacara yang harus di lakukan, salah satunya adalah penegasan judul. Penegasan judul dalam penelitian ini sangat di perlukan, supaya tidak menimbulkan kesalahpahaman tentang judul skripsi yang akan dilakukan. Adapun judul skripsi yang di maksudkan dalam penelitian ini adalah KARAKTERISTIK MORFOLOGI SPORA TUMBUHAN PAKU (PTERIDOPHYTA) PADA KELAS FILICINAE (PAKU SEJATI) DI GUNUNG TANGGAMUS LAMPUNG. Adapun uraian pengertian beberapa istilah yang terdapat pada judul skripsi ini yaitu sebagai berikut :

Karakteristik berasal dari kata karakter yang berarti sifat-sifat, sedangkan karakteristik dalam KBBI dapat diartikan sebagai sifat khas yang sesuai denganperwatakan tertentu. ${ }^{1}$ Karakteristik dalam ilmu biologi dapat dikaitkan dengan anatomi dan ciri khas dari tumbuhan atau hewan. Misalnya pada tumbuhan memiliki akar, batang dan daun sejati.

Ilmu biologi kata morfologi diartikan sebagai ilmu yang mempelajari mengenai bentuk dari suatu organisme, terlebih untuk hewan dan tumbuhan dan mencangkup bagian-bagiannya. ${ }^{2}$ Kata morfologi juga dapat di pakai dalam beragam bidang ilmu. Secara harfiah, morfologi di artikan sebagai ilmu

\footnotetext{
${ }^{1}$ KBBI, "Karakteristik," 13 Januari 2020 (Online), 2020, https://kbbi.web.id/karakteristik. ${ }^{2}$ KBBI, “Morfologi,” 16 Januari 2020 (Online), 2020, https://kbbi.web.id/morfolog.
} 
pengetahuan tentang bentuk atau struktur tubuh makhluk hidup yang berada di luar.

Sorus merupakan kumpulan dari spora yang berada di bawah permukaan daun. Spora merupakan bagian yang sangat penting pada tumbuhan paku karena berfungsi untuk perkembangbiakan dalam regenerasi. Spora di bentuk didalam kotak spora (sporangium). Kumpulan dari sporangium akan membentuk sorus. ${ }^{3}$ Penelitian ini akan mengidentifikasi mengenai bentuk, letak dan warna sorus pada tumbuhan paku.

Tumbuhan paku (Pteridophyta) merupakan tumbuhan perintis yang dapat hidup hampir di semua tempat, tumbuhan paku yang hidup di hutan memegang fungsi serta peran penting dalam menjaga ekosistem hutan. Pteridophyta telah memiliki sistem pembuluh sejati (kormus), akan tetapi tidak dapat menghasilkan biji dalam reproduksinya dan untuk perkembangbiakan menggunakan spora sebagai alat generatifnya. ${ }^{4}$

Kelas Filicinae (Paku Sejati) memiliki anggota paling besar dari kelas lainnya terdapat sekitar 170 genus dan 7000 spesies. $^{5}$ Kelas ini sering disebut juga dengan pakis atau paku sebenarnya. Tumbuhan ini termasuk kedalam tumbuhan higrofit, yaitu tumbuh di tempat-tempat teduh, dan lembab, sehingga untuk

\footnotetext{
${ }^{3}$ Ainol Mardiyah, Hasanuddin, and Eriawati, "Karakteristik Warna Sorus Tumbuhan Paku Di Kawasan Gunung Paroy Kecamatan Lhoong Kabupaten Aceh Besar,” Prosiding Seminar Nasional Biotik 2016, 2016, 220-28.

${ }^{4}$ Akbar Aji Seno, Vidhy Setyantoro, and Budhi Utami, "Profil Karakteristik Bentuk Sorus Tumbuhan Paku Di Kawasan Wisata Air Terjun Ironggolo Kabupaten Kediri," Prosiding Seminar Nasional IX Biologi FKIP UNS, 2012, 460-67, http://jurnal.fkip.uns.ac.id/index.php/prosbio/article/view/1127.

${ }^{5} \mathrm{~N}$ Nurchayati, "Identifikasi Profil Karakteristik Morfologi Spora Dan Prothalium Tumbuhan Paku Familia Polypodiaceae," Bioedukasi 15, no. 2 (2016): 25-30.
} 
tempat yang terbuka dan terpapar oleh sinar matahari langsung akan mengalami kerusakan atau mati. ${ }^{6}$

Gunung Tanggamus merupakan gunung tertinggi kedua di Lampung setelah Gunung Pesagi di Lampung Barat. Gunung Tanggamus dalam jurnal LIPI di sebutkan bahwa lahan-lahan di Hutan Lindung Gunung Tanggamus sudah mulai berkurang, sehingga tanaman dan hewan di wilayah ini harus diwaspadai. ${ }^{7}$

Jadi yang di maksud penulis dalam judul skripsi ini mengenai \begin{tabular}{llllll} 
KARAKTERISTIK & \multicolumn{2}{c}{ MORFOLOGI SPORA TUMBUHAN PAKU } \\
(PTERIDOPHYTA) & PADA KELAS FILICINAE & (PAKU SEJATI) DI
\end{tabular} GUNUNG TANGGAMUS LAMPUNG adalah untuk melakukan penelitian mengenai bentuk, warna dan letak persebaran spora pada kelas filicinae yang tumbuh epifit dan terestrial di Gunung Tanggamus Lampung.

\section{B. Alasan Memilih Judul}

Adapun alasan-alasan penulis tertarik dalam memilih dan menentukan judul tersebut adalah sebagai berikut :

1. Alasan Objektif

a. Pengurangan lahan di Hutan Lindung Gunung Tanggamus semakin tinggi.

\footnotetext{
${ }^{6}$ Tjitoseopomo Gembong, Taksonomi Tumbuhan (Yogyakarta: Universitas Gadjah Mada, 1989).

${ }^{7}$ Muhamad Muhaimin, Intani Quarta Lailaty, and Imawan Wahyu Hidayat, "Keragaman Tumbuhan Di Kawasan Hutan Lindung Gunung Tanggamus, Lampung Dan Upaya Konservasinya (Plants Diversity in Mount Tanggamus Protected Forest, Lampung and Its Conservation Efforts)," Pros. Sem. Nas. Masy. Biodiv. Indon. 4, no. 2 (2018): 144-50, https://doi.org/10.13057/psnmbi/m040208
} 
b. Penelitian mengenai karakteristik spora tumbuhan paku belum pernah di lakukan.

c. Adanya diagnosa perbedaan antara spora tumbuhan paku terestrial dan epifit berdasarkan bentuk, ukuran, tipe ornamentasi, jenis apetura pada kelas Filicinae.

2. Alasan Subjektif

a. Berdasarkan aspek dalam penelitian mengenai permasalahan tersebut, serta dengan tersedianya literatur yang dapat menunjang, maka sangat mungkin dilakukannya penelitian ini.

b. Pokok bahasan mengenai penelitian ini dapat menjadi disiplin ilmu yang di pelajari di Jurusan Biologi, Fakultas Tarbiyah dan Keguruan UIN Raden Intan Lampung.

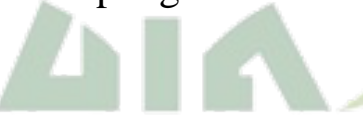

\section{Latar Belakang}

Negara Kesatuan Republik Indonesia (NKRI) berada di antara dua benua dan dua samudera, serta merupakan pertemuan dua kawasan biogeografi yaitu Oriental dan Australian. Peneliti dari berbagai negara sudah meneliti kekayaan alam yang ada di Indonesia. Selain itu, beberapa negara juga sudah ada yang menguasai negara ini. Indonesia juga memiliki pulau yang sangat banyak sekitar 18.000 pulau termasuk pulau besar dan kecil. ${ }^{8}$

\footnotetext{
${ }^{8}$ Endang Sukara and Imran SL Tobing, "Industri Berbasis Keanekaragaman Hayati, Masa Depan Indonesia," Vis Vatalis 1, no. 2 (2008): 1-12.
} 
Indonesia merupakan negara dengan iklim tropis dan letak geografisnya yaitu $6^{\circ} \mathrm{LU}-11^{\circ} \mathrm{LS}$ dan antara $95^{\circ} \mathrm{BT}-141^{\circ} \mathrm{BT}$. Wilayah Indonesia didominasi dengan pegunungan. Hijaunya pegunungan inilah yang menyebabkan Indonesia termasuk kedalam negara dengan keanekaragaman hayati kedua yang tinggi di dunia. ${ }^{9}$

Hutan hujan tropis Indonesia memiliki jenis tumbuhan dan ekosistem yang paling kompleks. Terdapat 25 ribu sampai 35 ribu jenis tumbuhan yang telah di temukan di Wilayah ini. Oleh karena itu, inventarisasi flora dibutuhkan adanya taksonom. Tingginya jumlah taksonom di daerah akan sangat berdampak pada inventaisasi flora di Indonesia. ${ }^{10}$

Seperti dalam Firman Allah SWT, Surat Al-An'am ayat 99
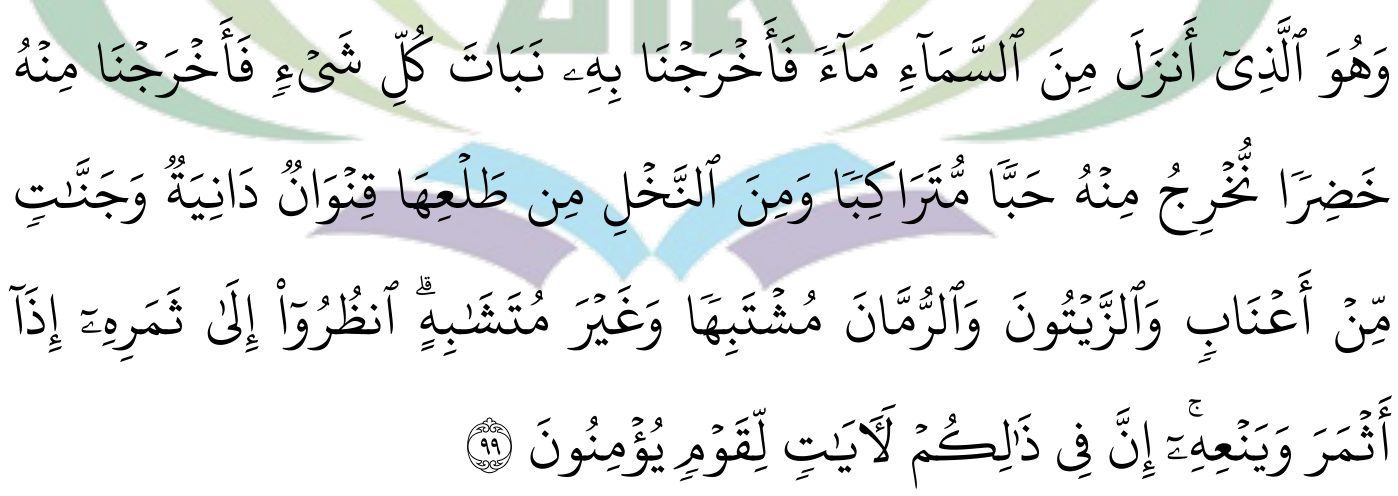

Artinya : "Dialah yang menurunkan air hujan dari langit. Lalu, kami tumbuhkan dengan air itu segala macam tumbuh-tumbuhan, maka Kmai keluarkan dari tumbuh-tumbuhan itu tanaman yang menghijau. Kami keluarkan dari

\footnotetext{
${ }^{9}$ Ainol Mardiyah, Hasanuddin, and Eriawati, "Inventarisasi Jenis Paku Di Kawasan Gunung Paroy Kecamatan Lhong Kabupaten Aceh Besar," Prosiding Seminar Nasional Biotik, 2017, 476-85, https://jurnal.ar-raniry.ac.id/index.php/PBiotik/article/view/2147.

${ }^{10}$ Relita Imaniar and Siti Murdiyah, "Identifikasi Keanekaragaman Tumbuhan Paku Di Kawasan Air Terjun Kapas Biru Kecamatan Pronojiwo Kabupaten Lumajang SertaPemanfaatannya Sebagai Booklet,” Jurnal Pendidikan Biologi 6, no. 3 (2017): 337-45.
} 
tanaman yang menghijau itu butir yang banyak; dan dari mayang kurma mengurai tangka-tangkai yang menjulai, dari kebun-kebun anggur, dan (Kami keluarkan pula) zaitun dan delima yang serupa dan yang tidak serupa. Perhatikanlah buahnya di waktu pohonnya berbuah, dan (perhatikan pulalah) kematangannya. Sesungguhnya pada yang demikian itu ada tanda-tanda (kekuasaan Allah) bagi orang-orang yang beriman.” (Q.S Al-An'am : 99)

Air dalam Al-Qur'an sering di bicarakan mengenai kehidupann dan tumbuhan pepohonan. Peran air dalam menumbuhkan segala sesuatu diketahui oleh semua orang baik primitif sampai modern. Air terlibat dalam perubahan permukaan tanah yang bisa di tanami dengan bantuan Allah SWT. Permukaan daun pada masa pertama memiliki panas yang sangat membara, kemudian menjadi keras membantu tanpa adanya tanah yang dapat di tumbuhi, dengan adanya air dan faktor udara, permukaan bumi menjadi tanah gembur yang dapat di tumbuhi berbagai tanaman. Air selalu berperan dalam menuburkan tanah. Setiap kali ada petir maka Allah akan menurunkan nitrogen-ozote dari langit yang dapat larut dalam air, sehingga membuat tanah menjadi subur, inilah yang dinamakan pupuk oleh manusia. Manusia membuat pupuk dengan cara yang sama. Pertumbuhan pohon akan selalu dimulai dengan warna hijau. Kata "khadhr" lebih besar maknanya dan lebih dalam dari kata "akhdhar". Pohon yang hijau ini "dari keluar butir yang banyak", seperti padi dan gandum. ${ }^{11}$

\footnotetext{
${ }^{11}$ Sayyid Quthb, Tafsir Fi Zhilail Qur'an Jilid 4 (Beirut: Darusy-Syuruq, 1992).
} 
Ayat ini menyampaikan kepada kita, "Makanlah buahnya ketika sudah berbuah!" Namum, ia berkata, "Perhatikanlah buahnya di waktu pohonya berbuah, dan (perhatikan pulalah) kematangannya." Karena konteks pembicaraan disini adalah tentang keindahan dan kenikmatan.juga konteks pembicaraan untuk mentadabburi tanda-tanda kekuasaan Allah, dan Keagungan ciptaanya-Nya dalam lingkup kehidupan. ${ }^{12}$

Tafsir pada ayat diatas dapat di simpulkan bahwa Allah SWT, telah menurunkan hujan dan menumbuhkan berbagai tanaman untuk makhluk yang ada didunia. Allah juga memerintahkan umatnya untuk melindungi apa yang telah Allah ciptakan. Manusia di muka bumi ini banyak yang bersifat sombong dan serakah dan menghalalkan berbagai cara untuk keinginannya tercapai walau hingga merusakk alam.

Hutan tropis gunung di Sumatera memiliki kekayaan alam yang besar dibandingkan dengan daerah lain. Asia Tenggara memiliki laju deforestasi yang tinggi di bandingkan dengan kawasan lain. Selain itu dinyatakan pula bahwa pada tahun 2100 adanya pengurangan keanekaragaman sekitar $18-85 \% .{ }^{13}$ Gunung Tanggamus berada di Kabupaten Tanggamus Provinsi Lampung merupakan Gunung tertinggi kedua di Lampung setelah Gunung Pesagi di Lampung Barat. Gunung Tanggamus memiliki kekayaan alam yang cukup baik. Banyak pendaki gunung yang melintasi Gunung Tanggamus, karena memiliki kekayaan dan

\footnotetext{
${ }^{12}$ Quthb.

${ }^{13}$ MUHAMMAD EFENDI, "Komposisi Dan Keanekaragaman Flora Di Gunung Pesagi, Sumatera," Jurnal Pros Sem Nas Masy Biodiv Indon 2, no. 2010 (2016): 198-207, https://doi.org/10.13057/psnmbi/m020214.
} 
pemandangan yang indah. Keanekaragaman tumbuhan yang terdapat di GunungTanggamus salah satunya adalah tumbuhan paku (pteridophyta). Tumbuhan yang ada di bumi ini mempunyai nama yang berbeda-beda dimana kita tinggal, misalkan di Indonesia buah apel, di Korea dinamakan "sagwa", di Inggris "apple". Oleh karena itu pemberian nama ilmiah dalam tumbuhan akan sangat berguna. Pemberian nama tumbuhan dapat dilakukan dengan mengidentifikasi atau determinasi.

Tumbuhan yang ada di muka bumi ini melingkupi 300.000 jenis tumbuhan dengan divisi yang berbeda. Setiap divisi akan di bagi menjadi takson yang lebih rendah, yakni kelas, bangsa (ordo), suku (famili), marga (genus), dan spesies (jenis). Determinasi nama tumbuhan di tentukan menggunakan Kode Internasional Tata Nama Tumbuhan, selain digunakan untuk menamakan tumbuhan dapat juga di gunakan sebagai sarana referensi keilmuan. Pada abad 20 ahli taksonomi membagi tumbuhan menjadi 5 divisi yakni, tumbuhan belah (Schizophyta), mempunyai 35.000 jenis, tumbuhan talus (Thallophyta) 60.000 jenis, tumbuhan lumut (Bryophyta) 25.000 jenis, tumbuhan paku (Pteridophyta) 10.000 jenis tumbuhan dan tumbuhan biji (Spermatophyta) 170.000 jenis tumbuhan. ${ }^{14}$ Data dari tiap jenis tumbuhan akan terus berganti, dapat berkurang dan dapat pula bertambah jumlah spessies tumbuhan yang terdaftar.

Pteridopyta mempunyai ukuran, bentuk, struktur serta fungsi tubuh bervariasi, ukuran tubuhnya ada yang berukuran $2 \mathrm{~cm}$ hingga 5 meter. Tumbuhan paku yang memiliki ukuran tubuh yang kecil biasanya hidup hygrofit / aquatik (hidup di air),

${ }^{14}$ Gembong Tjitoseopomo, Taksonomi Tumbuhan (Yogyakarta: Universitas Gadjah Mada, 1989). h 1 
sedangkan untuk ukuran tubuh yang besar merupakan tumbuhan paku terestrial. Bentuk tumbuhan paku (Pteridophyta) yang hidup saat ini masih bervariasi, ada berbentuk lembaran, perdu atau dapat juga memiliki bentuk seperti pohon, dan ada yang mirip seperti tanduk rusa. Tumbuhan paku memiliki zat hijau daun (klorofil) yang berfungsi untuk memasak makanan (fotosintesis). ${ }^{15}$

Tumbuhan paku di bagi menjadi 4 kelas yaitu psilophytinae, lycopodiinae, equisetinae dan filicinae. Psilophytinae (paku purba/paku telanjang), paku ini tidak memiliki daun atau mikrofil (daun-daun kecil) yang belum berdiferensiasi. Ada sebagian juga dari paku purba yang tidak memiliki akar. ${ }^{16}$ Kelas Lycopodinae, banyak dari jenis ini hidup secara epifit (hidup menempel di pohon atau di tanaman lain akan tetapi bukan sebagai parasit). Paku kawat ini banyak hidup dan tumbuh di hutan yang berikilim sedang tidak terlalu panasa dan tidak terlalu dingin. Pada beberapa spesies dari paku kawat, gametofit ada yang hidup di atas tanah dan bersifat fotosintetik. Dan sebagian lain hidup di bawah tanah atau tertanam, dan memperoleh makanan atau nutrisi dari fungsi simbiotik yang di lakukannya. ${ }^{17}$

Kelas Filicinae dapat di katakan sebagai paku sejati. Filiciinae berasal dari kata filix yang berarti tumbuhan paku sejati. Tumbuhan paku ini mempunyai daun yang berukuran besar dan duduk daunnya menyirip. Tumbuhan paku pada kelas ini ada yang hidup di air dan ada yang hidup di darat. Tumbuhan paku yang hidup

\footnotetext{
${ }^{15}$ Armelia Elsifa and Harmoko, "Eksplorasi Tumbuhan Paku ( Pteridophyta ) Di Stl Ulu Terawas, Musi Rawas, Sumatera Selatan,” Jurnal Tadris Biologi 10, no. 1 (2019): 47-55.

${ }^{16}$ Tjitoseopomo, Taksonomi Tumbuhan.

${ }^{17}$ Neil A \& B. Jane Campbell, Biologi Jilid 2 Edisi Ke Delapan (Jakarta: Erlangga, 2008).
} 
di darat sporangiumnya terbentuk dalam sorus, sedangkan yang hidup di air sporangiumnya terbentuk dalam sporokarpium. Tumbuhan paku pada kelas ini juga mempunyai daun muda yang menggulung dan sorus dibentuk dibawah permukaan daun. ${ }^{18}$ Tumbuhan paku yang hidup secara terestrial dan epifit memiliki perbedaan bentuk dan ukuran. Paku epifit tumbuh dengan menempel pada batang inang, memiliki batang yang pendek dan ukuran lebih kecil di bandingkan dengan paku terestrial.

Tumbuhan paku ialah tumbuhan berpembuluh primitif, dan sudah melakukan banyak evolusi yang ditandai dengan tingkat hidup di kondisi kering pada dinding sporanya. Tumbuhan paku hidup dengan adanya beberapa faktor yang mendukung pertumbuhannya yang utama adalah suhu. Tumbuhan paku hanya hidup di tempat yang lembab dengan suhu antara $13^{\circ} \mathrm{C}-21^{\circ} \mathrm{C}$. Faktor pendukung pertumbuhan paku selanjutnya yaitu $\mathrm{pH}$ tanah, udara, kelembapan tanah dan kelembapan udara. Spora tumbuhan paku pada umumnya terletak dibawah permukaan daun. Spora mengandung materi genetik yang berfungsi dalam proses pertumbuhan yang berakibat adanya pertumbuhan gametofit. Identifikasi spora yang pertama kali di lakukan yaitu pengamatan apertura. Apertura ialah bagian yag tipis dari eksin yang dapat berdiri sendiri pada pola eksin. Pengamtan selanjutnya ialah pada bentuk spora. Bentuk spora dapat dilihat secara berbeda-beda bergantung dari sudut pandang distal, polar dan equator. ${ }^{19}$

\footnotetext{
${ }^{18}$ Firda Ama Zulfia et al., "Keanekaragaman Spora Pteridophyta Sekitar Kampus Sebagai Media Pembelajaran Realia Mahasiswa Calon Guru Biologi Universitas Negeri Malang Abstrak," Prosding Semnas Hayati JV, 2016, 193-98.

${ }^{19}$ Eko Sri Sulasmi and Kata Kunci, "Analisis Kekerabatan Spora Tumbuhan Paku Koleksi Herbarium Malangensis,” Jurnal Biologi: Prosding Seminar Nasional Hayati V, 2017, 162-69.
} 
Pada jurnal LIPI tahun 2018 yang melakukan penelitian di Gunung Tanggamus di dapatkan hasil bahwa : Jenis-jenis tumbuhan yang telah tercatat selama eksplorasi pada umumnya banyak di temukan berupa jenis-jenis tumbuhan yang berada pada zona pegunungan bawah atau sub montana (1000-1500 mdpl), karena mayoritas dari data yang didapat tersebut digunakan juga sebagai dasar dalam pengoleksian tumbuhan. Di samping itu, pada zona tersebut terancam oleh kegiatan perluasan lahan perkebunan dan permukiman penduduk, sehingga data keragaman tumbuhannya mendesak untuk segera diketahui. Jenis-jenis yang dicatat juga difokuskan pada jenis-jenis yang memiliki status konservasi tinggi (endemik, langka, dilindungi) dan yang berpotensi manfaat. Oleh karena itu, hasil eksplorasi ini tidak bisa digunakan untuk menggambarkan keseluruhan vegetasi di sepanjang jalur penelitian atau eksplorasi. ${ }^{20}$ Penelitian ini di lakukan di Gunung Tanggamus karena tumbuhan paku dapat tumbuh subur di zona montana dimana zona ini memiliki ketinggian \pm 1500 mdpl dan pada jurnal LIPI Gunung Tanggamus memiliki keanekaragaman tumbuhan yang tinggi dan banyak terdapat tumbuhan paku didalamnya.

Penelitian mengenai spora pada tumbuhan paku di wilayah Lampung belum pernah di lakukan, sehingga memicu peneliti untuk meneliti mengenai “Karakteristik Tumbuhan Paku (Pteridophyta) pada Kelas Filicinae (Paku Sejati) Di Gunung Tanggamus".Penelitian ini dilakukan dengan menggunakan 3 ketinggian yaitu $1200 \mathrm{mdpl}, 1500 \mathrm{mdpl}$, dan $1800 \mathrm{mdpl}$, dengan perbedaan ketigian dalam pengambilan sampel ini dilakukan untuk mencari adanya

\footnotetext{
${ }^{20}$ Muhaimin, Lailaty, and Hidayat, "Keragaman Tumbuhan Di Kawasan Hutan Lindung Gunung Tanggamus , Lampung Dan Upaya Konservasinya Plants Diversity in Mount Tanggamus Protected Forest , Lampung and Its Conservation Efforts."
} 
keanekaragaman tumbuhan paku kelas Filiciae epifit maupun terestrial serta untuk mengetahui adakah perbedaan spora pada tiap-tiap ketinggian tersebut. Oleh karena itu, Penelitian ini diajukan guna memberikan tambahan wawasan kepada mahasiswa Universitas Islam Negeri Raden Intan Lampung mengenai perbedaan karakteristik spora pada tumbuhan paku epifit dan terestrial di Gunung Tanggamus.

\section{Identifikasi Masalah dan Batasan Masalah}

Berdasarkan latar belakang di atas, adapun masalah-masalah yang dapat di identifikasi yakni :

1. Belum adanya penelitian mengenai spora berdasarkan bentuk, ukuran, dan tipe/jenis apertura tumbuhan paku (pteridophyta) kelas filicinae di Gunung Tanggamus.

2. Membedakan sorus berdasarkan bentuk, warna dan letak persebarannya.

3. Perbedaan spora tumbuhan paku epifit dan terestrial berdasarkan morfologi letak, bentuk, dan warna.

Batasan masalah dalam karya ilmiah dapat dikatakan sebagai kerangka acuan, dalam menentukan fokus penelitian sehingga tidak keluar dari jalus penelitian antara lain :

1. Sampel data adalah spora dari tumbuhan paku kelas filicinae eifit dan terestrial yang di temukan di Gunung Tanggamus. 
2. Sampel di identifikasi secara morfologi sorus berdasarkan bentuk, warna dan letak spora, sedangkan untuk spora berdasarkan bentuk, ukuran, dan tipe/jenis apertura pada tumbuhan paku tersebut.

\section{E. Rumusan Masalah}

Rumusan masalah pada penelitian ini yaitu sebagai berikut :

1. Bagaimana morfologi, bentuk, warna dan letak persebaran sorus tumbuhan paku (pteridophyta) pada kelas filicinae di Gunung Tanggamus ?

2. Bagaimana morfologi bentuk, ukuran, dan tipe/jenis apertura tumbuhan paku pada kelas filicinae di Gunung Tanggamus?

3. Adakah perbedaan antara spora paku epifit dan paku terestrial berdasarkan spora pada sampel tersebut?

\section{F. Tujuan Penelitian}

Tujuan yang harus di capai pada penelitian ini yaitu sebagai berikut :

1. Untuk mengetahui morfologi bentuk, warna dan letak persebaran sorus tumbuhan paku (pteridophyta) pada kelas filicinae di Gunung Tanggamus.

2. Mengetahui morfologi bentuk, ukuran, dan tipe/jenis apertura tumbuhan paku pada kelas filicinae di Gunung Tanggamus.

3. Untuk mengetahui perbedaan spora antara paku epifit dan paku terestrial berdasarkan spora pada sampel tersebut. 


\section{G. Manfaat Penelitian}

Manfaat dalam penelitian ini adalah sebagai berkut :

1. Sumbangan kajian ilmiah dan sebagai pembendarahan karya ilmiah bagi Program Studi Pendidikan Biologi, Fakultas Tarbiyah dan Keguruan serta bagi Universitas Islam Negeri Raden Intan Lampung.

2. Sebagai sumber informasi bagi pembaca baik siswa, mahasiswa, dosen maupun masyarakat mengenai morfologi spora tumbuhan paku yang di teukan di Gunung Tanggamus,dan sebagai referensi bagi siswa atau mahasiswa mengenai spora tumbuhan paku dalam kegiatan praktikum atau penelitian.

3. Untuk menjaga kelestarian hutan Lindung di Gunung Tanggamus Lampung

4. Untuk peneliti sebagai wadah untuk mengembangkan suatu wawasan keilmuan biologi. 


\section{BAB II}

\section{LANDASAN TEORI DAN PENGAJUAN HIPOTESIS}

\section{A. Pengertian Tumbuhan Paku (Pteridophyta)}

Pteridophyta (tumbuhan paku) merupakan tumbuhan yang sudah memiliki pembuluh darah (xilem dan floem), akan tetapi tumbuhan ini tidak dapat menghasilkan bunga dan biji. Tumbuhan paku dapat dikatakan sebagai tumbuhan vaskular yang paling beragam setelah spermatophyta (tumbuhan berbiji). ${ }^{21}$ Pteridophyta disebut sebagai tracheophyta berspora, yaitu kelompok tumbuhan yang berpembuluh dan berkembang biak dengan spora. ${ }^{22}$ Tumbuhan paku banyak yang berupa terna, dan akar yang menjulur ke tanah dan ental yang menyangga daun dengan ukuran bervariasi. Tumbuhan paku banyak yang mendominasi vegetasi sehingga membuat tempat tersebut seperti blukar yang luas dan menutup tumbuhan lain. Akibatnya tumbuhan lain yang tidak dapat melawan pertumbuhan pakutersebut mati.

Pteropsida yang pertama yakni tumbuhan paku yang hidup dari zaman Devon dan memiliki banyak spesies. Tumbuhan paku hidup di lingkungan yang lembab dan merupakan tumbuhan homospora (hanya menghasilkan satu macam spora). Terdapat sekitar 9500 spesies yang masih hidup didunia. Sebagian besar spesis

\footnotetext{
${ }^{21}$ Margareta Rahayuningsih, Mualimaturrochmah Mualimaturrochmah, and Amin Retnoningsih, "Species Richness of Pteridophyta in Mount Ungaran," KnE Social Sciences 2019 (2019): 391-96, https://doi.org/10.18502/kss.v3i18.4730.

${ }^{22}$ Ayatusa'adah, "Inventarisassi Tumbuhan Paku (Pteridophyta) Di Kawasan Kampus IAIN Palangka Raya Sebagai Alternatif Media Pembelajaran Materi Klasifikasi Tumbuhan," Jurnal Pendidikan Sains \& Matematika 5, no. 2 (2017): 50-61.
} 
ini di temukan di daerah tropik dan ada yang dapat mencapai tinggi 13 meter dan lebih. $^{23}$

\section{B. Tempat Hidup Tumbuhan Paku}

Tumbuhan melakukan adaptasi secara morfologi pada tempat hidupnya untuk mempertahahankan hidupnya.

\section{Epifit}

Epifit merupakan suatu tumbuhan yang dalam hidupnya tidak hidup di tanah, atau menempel seperti di pohon, batu dan sebagainya. Tumbuhan yang tergolong tumbuhan epifit yaitu lumut, paku, anggrek, terna dan semak. Karakteristik utama dari epifit yaitu tumbuhan ini pada masa hidupnya menempel dapat pada pohon, bebatuan, tanah di permukaan hutan yang lembab, sampah dedaunan dan pohon yang telah tumbang. Tumbuhan ini dapat hidup di ketinggian sekitar 800-1000 dpl (dataran tinggi) sehingga di tempat ini curah hujan cukup tinggi. Epifit melakukan fotosintesis untuk pertumbuhannya sehingga epifit bukan parasit. Tumbuhan epifit juga mempunyai nilai ekologi dalam tempat hidup semut pohon. Tumbuhan paku epifit yang berukuran besar berasal dari genus Asplenium dengan daun memanjang hingga 1 meter. Beberapa jenis tumbuhan epifit memanjang dan akar melingkar sepanjang batang / dahan tumbuhan. ${ }^{24}$ Identifikasi jenis paku-pakuan

\footnotetext{
${ }^{23}$ W Jhon Kimball, Biologi Jidil 3 Edisi Kelima (Bogor: Intitut Pertanian Bogor, 1983).

${ }^{24}$ EFRI ROZIATY, PUTRI AGUSTINA, and RIZKA NURFITRIANTI, "Pterydophyta Epifit Kawasan Wisata Air Terjun Jumog Ngargoyoso Karanganyar Jawa Tengah,” Bioedukasi: Jurnal Pendidikan Biologi 9, no. 2 (2016): 76, https://doi.org/10.20961/bioedukasi-uns.v9i2.8586.
} 
epifit dalam berbagai jenis pohon, inang tempat pertumbuhan tanaman pakupakuan berbeda tergantung pada kondisi iklim mikro. ${ }^{25}$

\section{Terestrial}

Tumbuhan terestrial merupakan tumbuhan yang dalam periode hidupnya terkait dengan tanah atau permukan tanah. Tumbuhan jenis ini sangat banyak di muka bumi ini karena hidupnya alami. Seperti halnya tumbuhan, hewan terestrial adalah hewan yang hidup bebas berkeliaran diatas tanah, seperti harimau,biawak, dan lain-lain.

\section{Hidrofit}

Hidrofit (tumbuhan air) merupakan tumbuhan yang dapat menyesuaikan untuk hidup dilingkungan perairan. Tumbuhan ini dapat hidup terbenam seluruhnya atau hanya sebagian (bagian akar). Tumbuhan air sangat bergantung dengan air dalam masa hidupnya, bukan hanya tanah yang lembab atau berair. Istilah kata hidrofit dalam tumbuhan juga dapat dipakai untuk tumbuhan yang dapat hidup dengan kondisi tanah berair, akan tetapi dalam kesehariannya dapaat tumbuh dengan kandungan air normal. Tumbuhan paku yang termasuk hidrofit yaitu bangsa Salviniales, Spesies Ceropteris thalictroides). ${ }^{26}$

\footnotetext{
${ }^{25}$ Musriadi, "Identifikasi Tumbuhan Paku (Pteridophyta) Sebagai Bahan Ajar Botani Tumbuhan Rendah Di Kawasan Tahura Pocut Meurah Intan Kabupaten Aceh Besar," Jurnal Pendidikan Sains 05, no. 01 (2017): 22-31.

${ }^{26}$ Devi Lia Ariyanti, Windarti, and Efawani, "Types and Destiny of Aquatic in the Parit Belanda Swamp, Rumbai," Jurnal Online Mahasiswa Perikanan Dan Ilmu Kelautan Universitas Riau 17, no. 1-2 (2015).
} 


\section{Kelas Filicinae (Polypodiopsida)}

Kelas Filicinae memiliki anggota paling besar dari kelas lainnya terdapat sekitar 170 genus dan 7000 spesies. ${ }^{27}$ Kelas ini sering disebut juga dengan pakis atau paku sebenarnya. Tumbuhan ini termasuk kedalam tumbuhan higrofit, yaitu tumbuh di tempat-tempat teduh, dan lembab, sehingga untuk tempat yang terbuka dan terpapar oleh sinar matahari langsung akan mengalami kerusakan atau mati. ${ }^{28}$ Para ahli taksonomi menyatakan bahwa secara filogenetik familia Polypodiaceae (paku sejati) merupakan kumpulan paku-pakuan yang berbeda-beda. Familia tersebut mempunyai kesamaan pada annulus yang tidak lengkap dan tangkai sporangiumnya yang panjang. Tumbuhan paku familia Polypodiaceae merupakan kelompok polyphyletic, yaitu merupakan sekelompok paku-pakuan dengan anggota yang mempunyai jalur keturunan yang berbeda-beda.

Kelas Filicinae memiliki tipe daun makrofil (besar), bertangkai dan terdapat tulang-tulang daun. Daun muda tergulung pada ujung daunnya. Sisi bawah daun dewasa akan terdapat sporangia. Pada dasarnya batang, tangkai dan daun tertutupi oleh lapisan berupa sisik yang dinamakan palea. $^{29}$ Kelas Filicinae termasuk kedalam subfilum Pteropsida, yang juga mencangkup gimnospermae dan angiospermae.

Kegiatan identifikasi dapat mengetahui tingkat keanekaragaman jenis tumbuhan. Indentifikasi tumbuhan paku berguna untuk mengetahui tata nama

\footnotetext{
${ }^{27}$ Nurchayati, "Identifikasi Profil Karakteristik Morfologi Spora Dan Prothalium Tumbuhan Paku Familia Polypodiaceae."

${ }^{28}$ Tjitoseopomo, Taksonomi Tumbuhan.

${ }^{29}$ Tjitoseopomo.
} 
tumbuhan tersebut dari regnum hingga tingkat spesies. Spesies tumbuhan paku dapat di tentukan dengan organ vegetatif serta organ generatif. Organ vegetatif terdiri atas akar, batang dan daun, sedangkan organ generatif terdiri atas spora, sporangium, anteridium, dan arkegonium. ${ }^{30}$

\section{Anak Kelas Eusporangiatae}

Tumbuhan paku yang tergolong dalam anak kelas ini kebanyakan berupa terna. Protalium di bawah tanah dan tidak berwarna, atau di atas tanah dan berwarna hijau. Protalium selalu mempunyai cendawan endofitik.

\section{a. Bangsa Ophioglossales}

Tumbuhan ini memiliki ciri-ciri batang pendek yang berada di dalam tanah. Pada bagian bawah batang memiliki protostele, sedangkan pada bagian atas telah melakukan deferensiasi pada berkas pengangkut. Famili Ophioglossaceae dapat hidup sebagai paku terestrial maupun epifit dan terbagi kedalam 3 genus :

1) Ophioglossum

Sporangium terdapat dua baris, letak bulir saling berhadapan, jika sporangium telah matang maka sporangium akan terbuka secara melintang. Daun bertepi rata atau dapat juga menggarpu 1-2 kali, bertulang jala dengan tidak memiliki ibu tulang yang nyata.

Contoh : Ophioglossum vulgatum yang hidup di Eropa, O. reticulatum yang hidup di Indonesia. ${ }^{31}$

\footnotetext{
${ }^{30}$ Herdina Sukma Pranita, Susriyati Mahanal, and Murni Sapta Sari, "KARAKTERISTIK SPORA TUMBUHAN PAKU ASPLENIUM KAWASAN HUTAN RAYA R . SOERJO," Jurnal Pendidikan 2, no. 4 (2017): 454-58.

${ }^{31}$ Tjitoseopomo, Taksonomi Tumbuhan.
} 
2) Botrychium

Genus ini memiliki ciri-ciri tangkai daun bercabang-cabang seperti malai. Sepanjang cabang-cabang terdapat sporangium yang tersusun dalam dua baris. Daun menyirip 1-4 kali, dengan tulang daun yang bercabang menggarpu. Habitatnya sebagai paku tanah (terestrial). Contoh : B. lunaria di Eropa, B. daucifolium dan B. ternatum di Indonesia

3) Helminthostachys

Sporangium berada di segala arah, pada saat sporangium telah matang akan retak secara membujur.

Contoh : H. zetlanica ${ }^{32}$

b. Bangsa Marattiales

Famili Marattiaceae di bagi menjadi 3 genus :

\section{1) Angiopteris}

Paku ini memiliki ukuran yang besar sehingga sering di sebut dengan "king of fern”. Tumbuhan ini memiliki ciri akar serabut, batang tegak dengan bentuk rimpang pendek, tinggi batang dapat mencapai $1 \mathrm{~m}$, batang bersisik-sisik pada bagian pangkal. Daun berwarnan hijau, menyirip tunggal, ujung anak daun meruncing. Sorus berada di bawah daun, meyebar tidak beraturan, bentuk bulat, warna coklat muda. ${ }^{33}$

Contoh : Angiopteris avecta

\footnotetext{
${ }^{32}$ Tjitoseopomo.

${ }^{33}$ Joko Widiyanto, Ayu Wulandari, and Maeheny Lukitasari, "Identifikasi Keragaman Paku Di Kawasan Wisata Mojosemi Forest Park," Prosding Seminar Nasional SIMBIOSIS II 2, no. September (2017): 434-42.
} 


\section{2) Marattia}

Genus ini memiliki bentuk yang besar dan hidup secara terestrial. Daun tegak dan menyirip. Sporangia menyatu menjadi sinangia. Sorus terletak di tepi daun.

\section{Contoh : Marattia alata, M. fraxinea}

\section{3) Christenesia}

Genus ini memiliki ciri daun menjari, daun beranak 3 atau 4-5. Sinangium berbentuk cincin, tersebar pada sisi bawah daun.

\section{Contoh : Christenesia aesculifolia ${ }^{34}$}

\section{Anak Kelas Leptosporangiatea (Filices)}

Tumbuhan ini paling banyak terdapat di daerah tropika, meliputi jenis-jenis paku dari yang terkecil (hanya beberapa mm saja) sampai yang terbesar (yang berupa pohon). Paku yang berupa pohon, batangnya dapat mencapai besar satu lengan atau lebih, umumnya tidak bercabang, dan pada ujungnya terdapat rozet daun. Daun-daun itu menyirip ganda, panjangnya dapat sampai dengan $3 \mathrm{~m}$, dan jika telah gugur meninggalkan bekas-bekas yang telah jelas pada batang. Kambium tidak ada, jadi batang tidak mengadakan pertumbuhan menebal sekunder dan tidak mempunyai bagian kayu. Kekuatan batang diperoleh dari berkas-berkas pengangkut yang mempunyai susunan konsentrik, lempenglempeng sklerenkim, dan batang diselubungi oleh akar-akar pendek yang kaku. ${ }^{35}$

\footnotetext{
${ }^{34}$ Tjitoseopomo, Taksonomi Tumbuhan.h. 260-261

${ }^{35}$ Eric Schuettpelz et al., "A Community-Derived Classification for Extant Lycophytes and Ferns," Journal of Systematics and Evolution 54, no. 6 (2016): 563-603, https://doi.org/10.1111/jse.12229.
} 


\section{a. Ordo Cyatheales}

\section{1) Famili Cyatheaceae}

Famili ini sering di sebut dengan paku tiang karena memiliki batang yang kuat. Akar berserabut, tinggi batang dapat mencapai 5 meter. Permukaan batang berduri berwarna merah kecoklatan. Memilki daun berukuran besar, daun majemuk menyirip ganda. Sporangium di dalam sorus terletak di bawah daun. Sorus berbentuk bola dan di lindungi lapisan indusium, sorus jika belum masak berwarna hijau sedangkan berwarna coklat jika telah masak. ${ }^{36}$

Klasifikasi

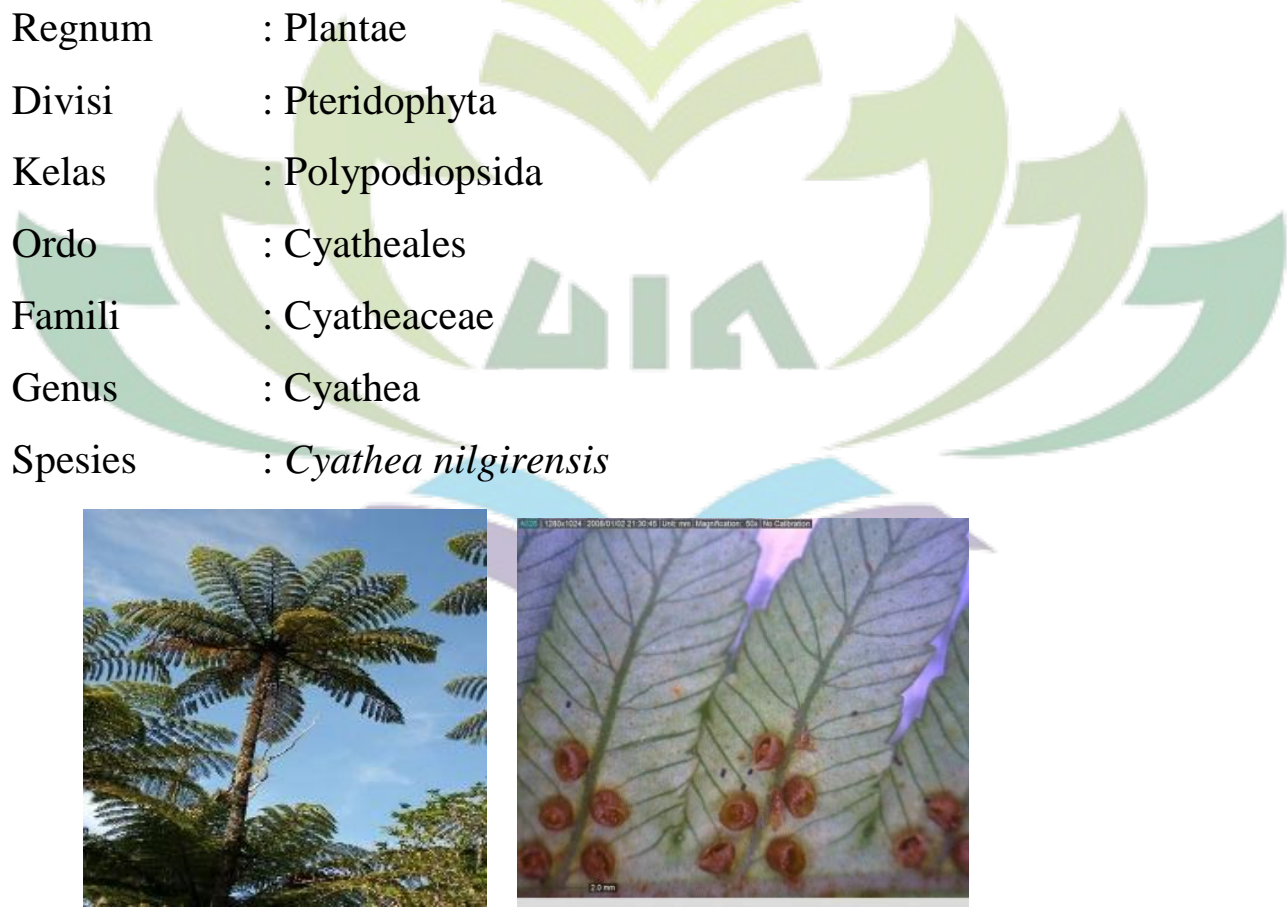

Gambar 2.2.1 (a) Pohon Cyathea nilgirensis ${ }^{37}$ (b) Spora $^{38}$

\footnotetext{
${ }^{36}$ Herdina Sukma Pranita et al., "Inventarisasi Tumbuhan Paku Kelas Filicinae Di Kawasan Watu Ondo Sebagai Media Belajar Mahasiswa 1," Seminar Nas Pendiddikan Dan Saintek, 2016, 733-40.

37،"Gambar Spesies Cyathea Nilgirensis,” wikipedia, 2020, https://en.wikipedia.org/wiki/Cyathea.

${ }^{38}$ Pranita et al., "Inventarisasi Tumbuhan Paku Kelas Filicinae Di Kawasan Watu Ondo Sebagai Media Belajar Mahasiswa 1."
} 
2) Famili Schizaeaceae

Sporangia tidak mempunyai tangkai, terpisah-pisah, jika telah matang maka akan membuka celah membujur.

a) Genus Scchizea

Genus yang terdapat di Indonesia yaitu S. Digitata, S. Dichotoma

b) Genus Lygodium

Lygodium sudah dikenal pada zaman tersier. Daun panjang, dan taju daun tersusun menyirip. Sporangia terdapat pada bagian daun. ${ }^{39}$

3) Famili Matoniaceae

Daun pada tanaman ini panjang dan menjari. Sporangium ditutupi oleh indusium yang berbentuk prisai. Protalium pada famili ini belum di kenali. Famili ini meliputi genus Matonia dan Phanerosorus. 40

4) Famili Loxsomaceae

Sporangium pada tanaman ini dapat membuka dengan celah membujur.

5) Famili Hymenophyllaceae

Sorus berada di tepi daun, memiliki indisium berbentuk piala. Protalium berbentuk pita atau benang. Paku ini terdapat hampir di seluruh daerah tropik, hidup secara epifit.

\footnotetext{
${ }^{39}$ Tjitoseopomo, Taksonomi Tumbuhan.h 272

${ }^{40}$ Tjitoseopomo. h 274
} 


\section{6) Famili Dicksoniaceae}

Pada genus Dicksonia mempunyai sorus berbentuk bulat atau sedikit memanjang, berdekatan dengan tepi daum pada ujung urat.

\section{b. Ordo Polypodiales}

1) Famili Polypodiaceae

a) Klasifikasi Pyrosia angustata

$\begin{array}{ll}\text { Regnum } & \text { : Plantae } \\ \text { Divisi } & : \text { Pteridophyta } \\ \text { Kelas } & \text { : Pteridopsida } \\ \text { Ordo } & \text { : Polypodiales }\end{array}$

Famili : Polypodiaceae

Genus : Pyrrosia

Spesies : Pyrrosia angustata

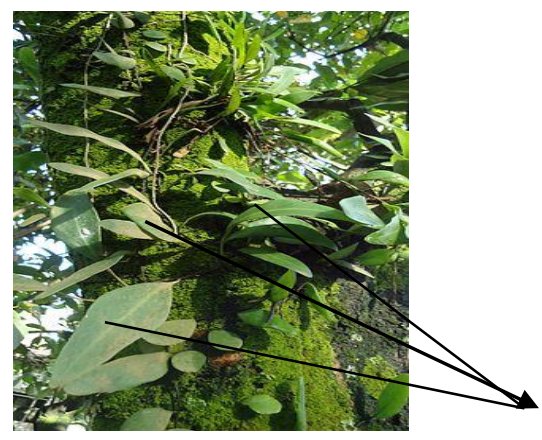

Gambar 2.2.2 Pyrrosia angustata ${ }^{41}$

41،"Gambar Pyrrosia Angustata," wikipedia, 2018, https://id.wikipedia.org/wiki/Pyrrosia. 
Pyrrosia angustata merupakan paku yang tumbuh secara epifit dan ada juga yang hidup secara likofit (menempel pada batu). Tumbuhan ini memiliki ciri-ciri akar rimpang berserabut. Batang menjalar, daun berwarna hijau, sedikit tebal, bentuk daun linear, memiliki tepi daun yang rata, panjang ukuran daun 5-15 cm. Letak sorus di bawah daun, memiliki warna sorus coklat dan bentuk bulat. ${ }^{42}$

\section{b) Klasifikasi Platycerium bifurcatum}

$\begin{array}{ll}\text { Regnum } & \text { : Plantae } \\ \text { Divisi } & \text { : Pteridophyta } \\ \text { Kelas } & \text { : Pteridopsida } \\ \text { Ordo } & \text { : Polypodiales } \\ \text { Famili } & \text { : Polypodiaceae } \\ \text { Genus } & \text { : Platycerium } \\ \text { Spesies } & \text { : Platycerium bifurcatum }\end{array}$

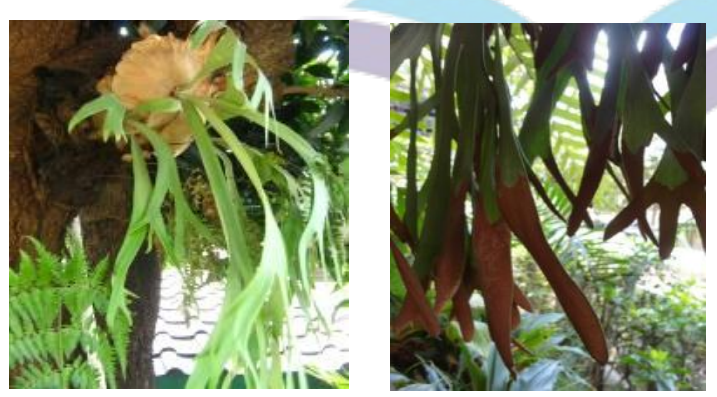

Gambar 2.2.3 (a) Pohon Platycerium bifurcatum(b) Spora

Platycerium bifurcatum hidup secara epifit, tumbuhan ini menempel sangat kuat pada pohon yang di tumpanginya, akan tetapi tidak bersifat parasit. Daun memiliki 2 tipe, daun steris mempunyai bentuk perisaitegak, dapat mengering jika

\footnotetext{
${ }^{42}$ Widiyanto, Wulandari, and Lukitasari, "Identifikasi Keragaman Paku Di Kawasan Wisata Mojosemi Forest Park."
} 
kondisi air kurang memadai. Daun fertil benbentuk ranggah rusa, pada bagian bawah terdapat spora. Spora memiliki bentuk sorus berwarna coklat. Batang berbentuk rimpang, batang dan akar melekat pada batang inang sehingga membentuk bongkahan.

c) Klasifikasi Dynaria sp.

Regnum : Plantae

Divisi : Pteridophyta

Kelas : Pteridopsida

Ordo : Polypodiales

Famili : Polypodiaceae

Genus : Dynaria

Spesies : Dynaria sp.

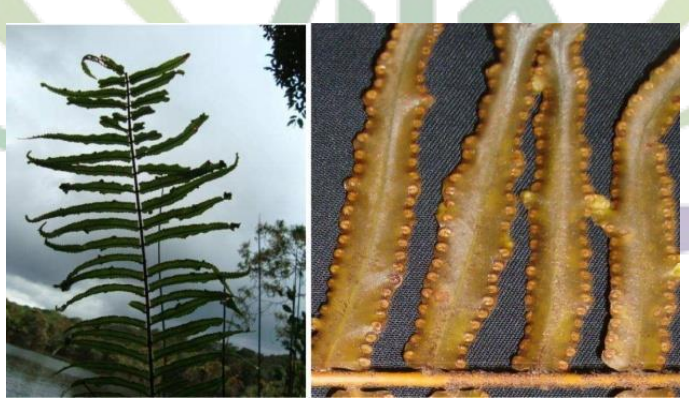

Gambar 2. (a) Dynaria sp. (b) sorus ${ }^{43}$

Tumbuhan paku spesies Dynaria sp., hidup secara terestrial, dengan keadaan yang lembab dan intensitas cahaya yang kurang. Daun pada tanaman ini berwarna hijau, dan menyirip ganda, sedangkan untuk panjangtangkai daun sekitar $\pm 30 \mathrm{~cm}$. sorus bersada dalam cekungan bulat dann memiliki warna coklat tua, spora tersebar di seluruh tepi daun.

\footnotetext{
${ }^{43}$ Melfa Aisyah Hutasuhut and Husnarika Febriani, "Keanekaragaman Paku-Pakuan Terestrial Di Kawasan Taman Wisata Alam Sicike-Cike,” Jurnal Biolokus 2, no. 1 (2019): 146-57.
} 
2) Famili Hypodematiaceae

Klasifikasi

Regnum : Plantae

Divisi : Pteridopyta

Kelas : Polypodiopsida

Ordo : Polypodoales

Famili : Hypodematiaceae

Genus : Didymochalena

Spesies : Didymochalena truncatula
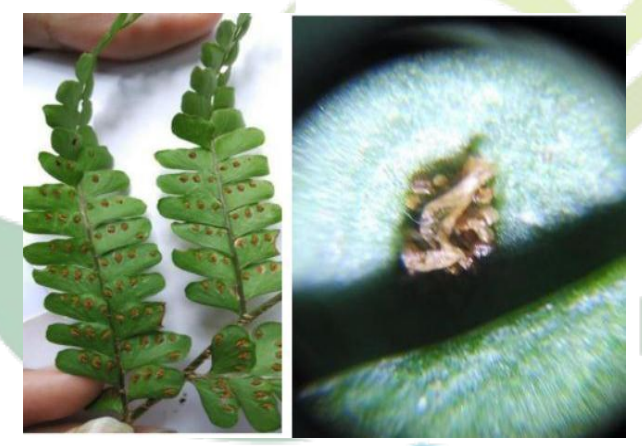

Gambar 2.2.4 Spora $^{44}$

Paku Sigung (Didymochlaena truncatula), memiliki bau yang sangat khas.

Tumbuhan ini memiliki sorus yang terletaak pada bagian sun marginal pinna dan dilindungi oleh insidium yang mempunyai bentuk round atau bulat.

\section{Anak Kelas Hydropterides (Paku Air)}

Pada tumbuhan paku hampir semua tanaman merupakan homosporus. Gametofit pada beberapa spesies dapat mengkerut dan mati setelah sporofit muda

\footnotetext{
${ }^{44}$ C Nugroho et al., "Karakteristik Tumbuhan Paku (Pteridophyta) Di Jalur Ciwalen, Taman Nasional Gunung Gede Pangrango, Cisarua, Jawa Barat," Biodidaktika 13, no. 1 (2018): 28-37, TI Sabrina BIODIDAKTIKA, JURNAL BIOLOGI DAN ..., 2018.
} 
melepaskan. Sporofit memiliki sporangium bertangkai dengan peralatan yang berupa pegas yang dapat melontarkan spora beberapa meter dari sel inangnya. Spora yang terbawa oleh angin dapat tersebar jauh dari tempat asalnya. Beberapa spesies dari jenis ini juga dapat menghasilkan lebih dari satu triliun spora selama masa hidupnya. ${ }^{45}$

a. Famili Salviniaceae

1) Genus Salvinia

2) Genus Azolla

Klasifikasi

$\begin{array}{ll}\text { Regnum } & : \text { Plantae } \\ \text { Divisi } & : \text { Pteridophyta } \\ \text { Kelas } & : \text { Pteridopsida } \\ \text { Ordo } & : \text { Salvinales }\end{array}$

Famili :Salviniaceae

Genus : Azolla

Spesies : Azolla $\mathrm{sp}$.

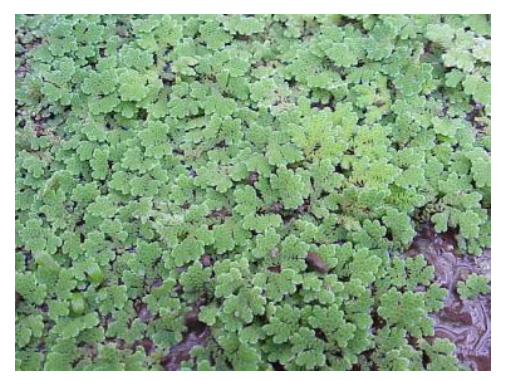

Gambar 2.3 Azolla sp. ${ }^{46}$

${ }^{45}$ Campbell, Biologi Jilid 2 Edisi Ke Delapan. h 180

46،"Gambar Spesies Azolla https://id.wikipedia.org/wiki/Berkas:Azolla_caroliniana2.jpg.

wikipedia, $\quad 2004$, 
Genus Azolla merupakan jenis tumbuhan paku hidrofit yang memiliki ukuran kecil. Azolla dapat mengikat nitrogen bebas yang terdapat di udara dengan bersimbiosis dengan Anabaena azollae. Azolla sp. dapat ditemukan di seluruh area persawahan Indonesia, tumbuhan ini juga hidup secara liar dan dapat berkembang tanpa di budidayakan. ${ }^{47}$

b. Famili Marsileaceae

1) Genus Marsilea

2) Genus Pilularia

3) Regnellidium

\section{Morfologi Filicinae}

1. Akar

Akar dari kelas Filicinae tumbuh dibawah tanah. ${ }^{48}$ Akar rimpang seringkali bersisik.

2. Batang

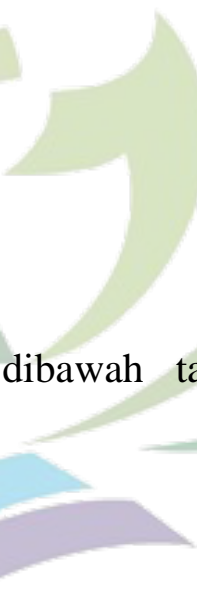

Batang tumbuhan ini sama halnya dengan akar tumbuh di bawah permukaan tanah. ${ }^{49}$ Tumbuhan ini tidak memiliki batang diatas tanah.

3. Daun

Karakteristik utama dari kelas Filicinae yaitu pada saat daun masih muda maka daun akar tergulung. Daun dapat tergulung di sebabkan oleh sel-sel

\footnotetext{
${ }^{47}$ W Mantang, F. R Mantiri, and B. J Kolondam, "Identifikasi Tumbuhan Paku Air (Azolla Sp.) Secara Morfologi Dan Molekuler Dengan Menggunakan Gen RbcL,” Jurnal Bioslogos 8, no. 2 (2018): 38-44, W Mantang, FR Mantiri, BJ Kolondam - BIOSLOGOS, 2018 - ejournal.unsrat.ac.id.

${ }^{48}$ Kimball, Biologi Jidil 3 Edisi Kelima. h 886

${ }^{49}$ Kimball.
} 
pada sisi bawah daun lebih cepat pertumbuhanya dan baru di tiadakan dengan terbukanya daun. Susunan dari daun telah menyerupai daun Spermatophyta. Daun-daun lembaga serta daun-daun pertama memiliki tulang daun yang bercabang menggarpu. Pertumbuhan daun banyak menimbulkan asumsi yani daun ini merupakan penjelmaan dari tunas dan akhirnya menghentikan pertumbuhananya. ${ }^{50}$ Tumbuhan paku memiiki beberapa jenis pola percabangan daun yang rumit, sehingga banyak dimanfaatkan sebagai hiasan.

\section{Daur Hidup (Metagenesis)}

Tumbuhan paku memiki sistem pembuluh sejati, akan tetapi dalam perkembangbiakan generatifnya masih menggunakan spora. Akar tumbuhan paku berasal dari embrio kemudian lenyap dan diganti dengan akar yang mirip seperti kawat atau serabut dan memiliki warna gelap dan dalam jumlah yang banyak. ${ }^{51}$ Perkembangbiakan tumbuhan paku secara aseksual dan seksual. Tumbuhan paku mengalami pergiliran dari generasi gametofit dan generasi sporofit (metagenensis). Generasi sporofit merupakan generasi yang dominan dalam daur hidup tumbuhan paku.

Famili Polypodiaceae, sporangium terkumpul membentuk sorus dengan bentuk yang bermacam-macam. Sorus berasal dari penonjolan daun yang disebutdengan tembuni (reseptakulum), sporangium yang belum masak akan

\footnotetext{
${ }^{50}$ Tjitoseopomo, Taksonomi Tumbuhan. h 105

${ }^{51}$ Mardiyah, Hasanuddin, and Eriawati, "Karakteristik Warna Sorus Tumbuhan Paku Di Kawasan Gunung Paroy Kecamatan Lhoong Kabupaten Aceh Besar."
} 
ditutupi oleh suatu selaput indusium. Sporangium yang terdiri dari satu tangkai dan kotak spora (kapsula) dan dindingnya terdiri atas satu lapis sel terbentuk dari satu sel epidermis. Isospora di dalam kotak spora terdapat sangat banyak. Pada dinding kotak spora terdapat deretan sel yang meilingkar yang merupakan cincin atau anulus. Organ reproduksi jantan disebut dengan antheridium (antherezoid) dan organ reproduksi betina disebut arkegonium (sel telur). Zigot diploid (2n) akan berkembang menjadi embrio. Sporofit muda akan tumbuh menjadi tanaman dewasa. $^{52}$

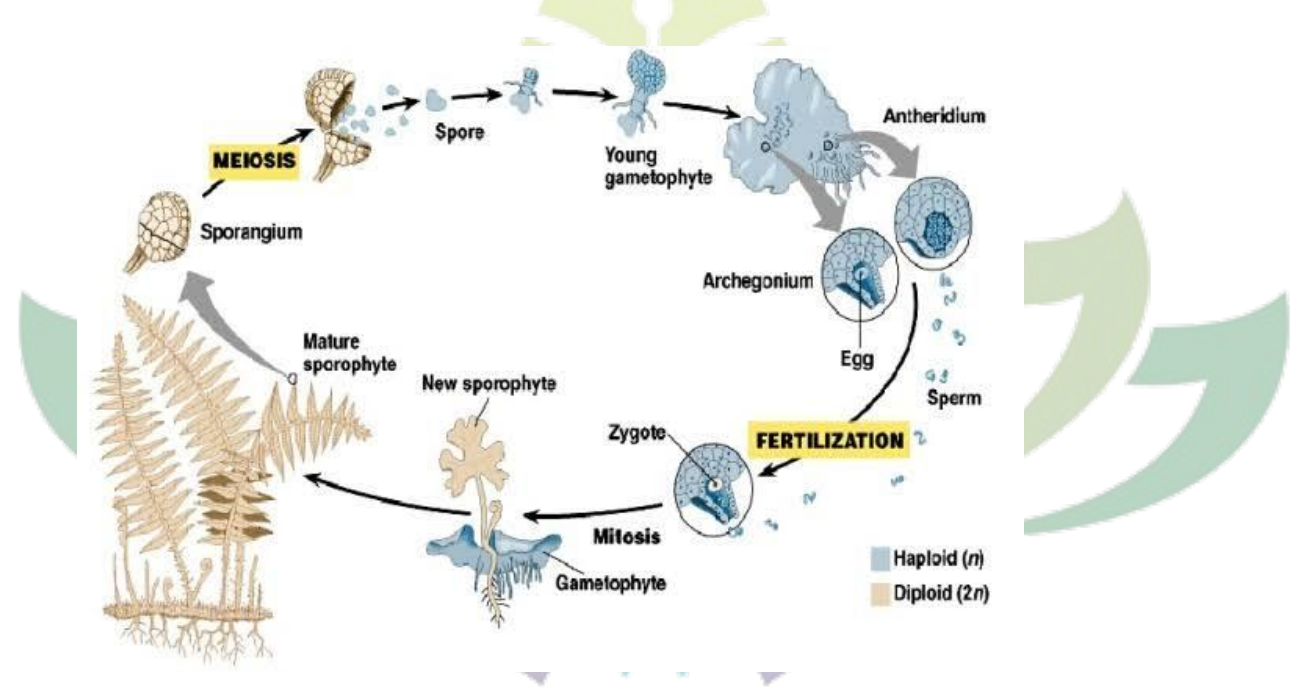

Gambar 2.4.1Daur Hidup Pteridophyta ${ }^{53}$

\section{E. Morfologi Spora}

Karakteristik morfologi spora dapat dilihat dengan bentuk, ukuran, tipe/jenis spora dan tipe ornamentasi eksin yang berbeda. Spora mempunyai struktur

\footnotetext{
${ }^{52}$ Teena Agrawal, Priyanka Danai, and Monika Yadav, "General Aspects of Pteridophyta - A Review," International Journal of Current Research and Academic Review 5, no. 3 (2017): 80-85, https://doi.org/10.20546/ijcrar.2017.503.012.

53،"Gambar Daur Hidup Pteridophyta," Ajaran Islam, 2019, http://islampedia10.blogspot.com/2019/01/embriogenesis-pteridofita.html.
} 
permukaan yang berbeda dari struktur halus hingga tidak beraturan. Lapisan pelindung spora di bagi menjadi dua, eksin (lapisan luar) dan intin (lapisan dalam). Ornamentasi eksin dapat di bedakan berdasarkan ukuran, bentuk dan susunan unsur ornamentasinya. Misalkan pada spesies Asplenium nidus memiliki lubang permukaan spora yang berukuran $1,98 \mu \mathrm{m}$. Asplenium robustum mempunyai tipe ornamentasi eksin psilate yakni seluruh permukaannya halus, rata dan licin. Sedangkan Asplenium tenerum mempunyai tipeeksin reticulate, karena bagian permukaan membentuk polaseperti jala, Asplenium unilaterale berbentuk seperti duri. $^{54}$

\section{Bentuk}

Tumbuhan paku memiliki dua bentuk spora yaitu monolet dan trilet. Bentuk spora monolet yaitu bentuk spora yang mirip dengan kacang merah dan memiliki sebuah sudut di sepanjang tepian yang melengkung kedalam. Spora trilet yaitu bentuk yang memiliki 3 permukaan dan membentuk sudut pada setiap pertemuan spora. Spora trilet merupakan bentuk spora yang paling banyak di temukan. Pada Famili Pteridaceae mempunyai bentuk spora monolet dan trilet. ${ }^{55}$ Spora monolet memiliki ciri garis tunggal yang mencirikan adanya bekas luka pada saat induk spora masak dan pecah serta terbagi menjadi 4 sel reproduktif disekitar axis vertikal. Induk spora trilet akan memecah menjadi empat sel reproduktif dan akan meninggalkan tiga garis yang menyebar di bagian

\footnotetext{
${ }^{54}$ Pranita, Mahanal, and Sari, "KARAKTERISTIK SPORA TUMBUHAN PAKU ASPLENIUM KAWASAN HUTAN RAYA R . SOERJO."

${ }^{55}$ Afni Atika Marpaung et al., "Morfologi Spora Paku Pteridaceae Di Hutan PT . CPI Rumbai Riau," Jurnal Riau Biologia 1, no. September (2016): 149-54.
} 
tengahnya. Pada tanaman Dryopteris concolor memiliki bentuk spora membulat (ovatus), pada Asplenium nidus berbentuk elips (elipticus). Nephlolepis falcate memiliki bentuk seperti ginjal. Bentuk spora segitiga (triangularis) contohnya Adiantum caudatum. ${ }^{56}$

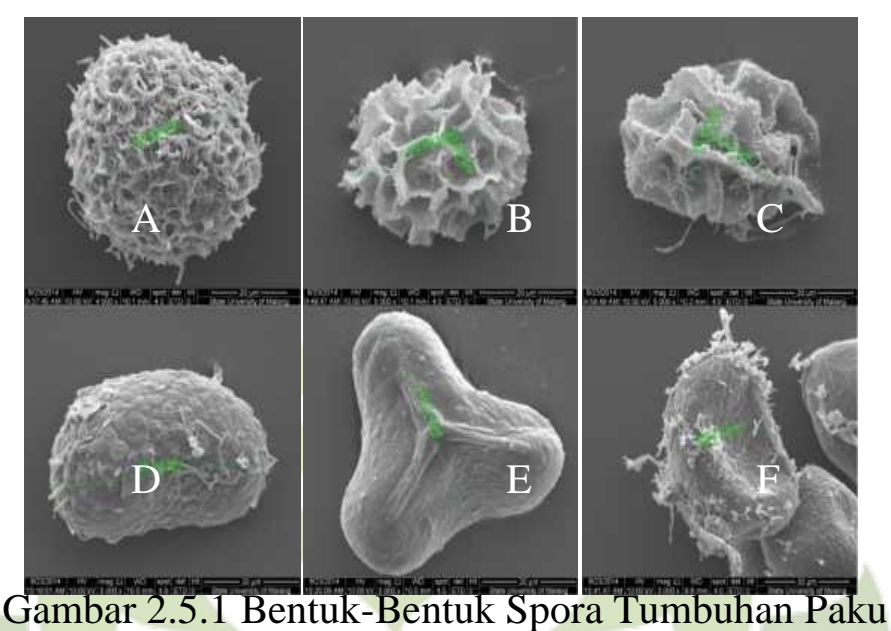

A. Bulat B. Tidak beraturan, C. Tidak beraturan, D. Elips, E Segitiga dengan sisi cembung dan dua sisi cekung, F. Elips ${ }^{57}$

2. Ukuran

Ukuran spora tumbuhan paku beragam. Menurut Erdman (1945) menyebutkan bahwa ukuran spora tumbuhan paku di bagi menjadi 6 yaitu : spora sangat kecil $(<10 \mu \mathrm{m})$, spora kecil $(10-25 \mu \mathrm{m})$, spora medium / sedang $(25-50 \mu \mathrm{m})$, spora besar (50-100 $\mu \mathrm{m})$, spora sangat besar $(100-200 \mu \mathrm{m})$ dan spora gigantik $(>200 \mu \mathrm{m})$. Selain ukuran spora juga memiliki tipe spora yaitu spora medium (2 jenis) dengan

\footnotetext{
${ }^{56}$ Nurchayati, "Identifikasi Profil Karakteristik Morfologi Spora Dan Prothalium Tumbuhan Paku Familia Polypodiaceae."

${ }^{57}$ Sulasmi and Kunci, “Analisis Kekerabatan Spora Tumbuhan Paku Koleksi Herbarium Malangensis.”
} 
ukuran 47,12 - 47,59 $\mu \mathrm{m}$ dan spora besar (4 jenis) memiliki ukuran 57,88 - 78,16 $\mu \mathrm{m} .{ }^{58}$

3. Warna

Warna spora pada tumbuhan paku bermacam-macam, yaitu sebagai berikut ini :

a. Sorus berwarna coklat

Sorus Paku Sarang Burung (Asplenium nidus L.), Paku Kenying (Asplenium macrophyllum Sw.), Paku Lubang (Blechnum indicum Burm.), Paku Perak (Pityrogramma tartarea Link.), Paku Ekor Merak (Pteris longifolia L.)

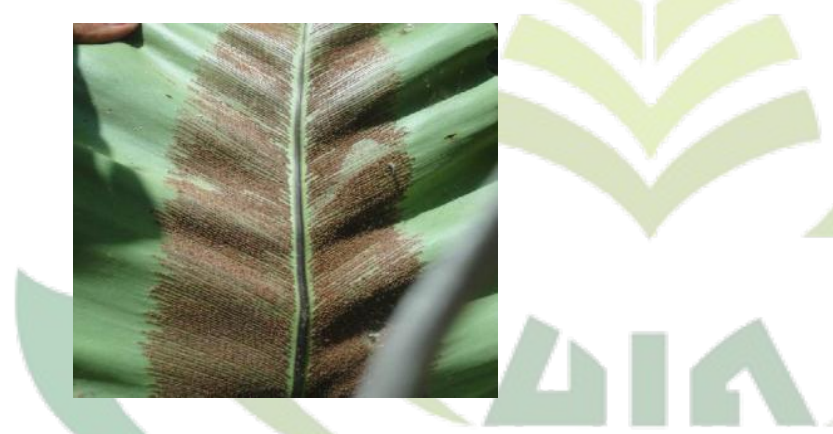

Gambar 2.5.2 Sorus Paku Sarang Burung ${ }^{59}$

b. Sorus berwarna kuning,

Sorus Paku Rasam (Gleichenia linearis Burm. F)

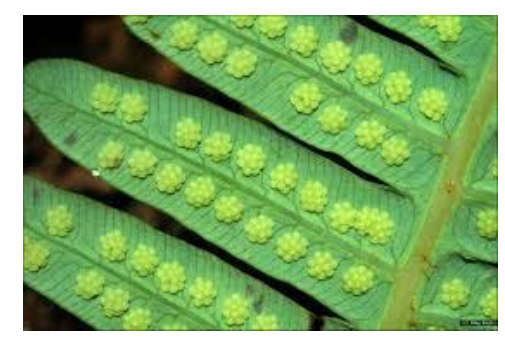

Gambar 2.5.3 Sorus Paku Rasam

\footnotetext{
${ }^{58}$ Sulasmi and Kunci.

${ }^{59}$ Mardiyah, Hasanuddin, and Eriawati, "Karakteristik Warna Sorus Tumbuhan Paku Di Kawasan Gunung Paroy Kecamatan Lhoong Kabupaten Aceh Besar."
} 
c. Sorus warna hitam

Sorus Paku Hata (Lygodium circinnatum Burm.F), Sorus Paku Kadal (Cyclosorus acuminata Houtt.), Sorus Paku Sayur (Diplazium dilatatum Blume.)

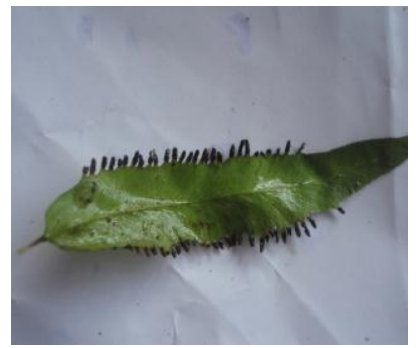

Gambar 2.5.4 Sorus Paku Hata ${ }^{60}$

d. Sorus memiliki warna coklat gelap bergaris,

Paku Pedang (Pteris ensiformis)

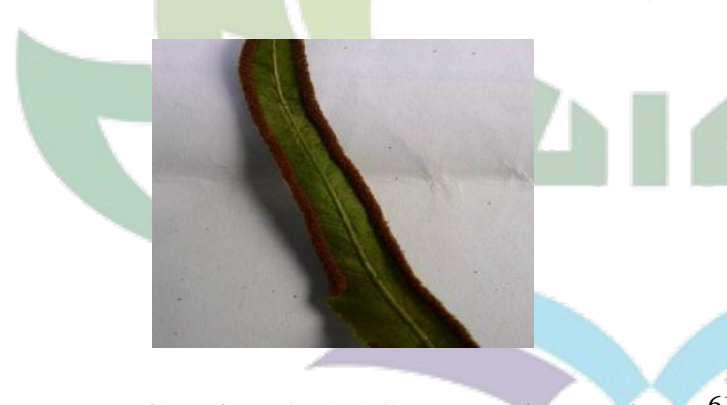

Gambar 2.5.5 Sorus Paku Pedang ${ }^{6}$

Kualitas udara mempengaruhi warna dari sorus. Udara mengandung senyawa kimia yang berasal dari pabrik, kendaraan maupun limbah hasil pembakaran bekas pakai. Tumbuhan paku yang menyerap zat-zat kimia dilakukan oleh daun, tingginya penyerapan zat kimia yang ada di udara akan berdampak pada perubahan organ-organ pada daun tumbuhan paku. Hal ini lah yang memicu variasi dari warna sorus tersebut.

${ }^{60}$ Mardiyah, Hasanuddin, and Eriawati.

${ }^{61}$ Mardiyah, Hasanuddin, and Eriawati. 


\section{Apertura}

Area berdinding pada bagian eksin (lapisan luar) spora dan tempat terjadinya perkecambahan disebut dengan apertura. Pada dasarnya ada spora tumbuhan paku yang memiliki apertura dan ada yang tidak. Apertura di lindungi oleh lapisan yang halus atau biasa di sebut dengan ornamentasi. Apertura dibagi menadi 2 jenis yaitu porus (pori/bulat) dan sulcus (colpi). ${ }^{62}$

Apertura tipe pori memiliki bentuk rongga isodiametris, akan tetapi berbentuk sedikit panjang dan membulat pada bagian akhirnya. Colpi ialah jenis apertura yang sedikit llebih primitif dibandingkan dengan tipe apertura pori. Jenis butir spora tipe colpi dinamakan dengan porate, jenis colpi dinamakan colpate, dan jenis kombinasi dinamakan colporate. ${ }^{63}$

Tipe-tipe apertura diindikasikan adalah Monolate, Trilate, Inaperturate. ${ }^{64}$ Tipe apertura pada kelas paku sejati lebih banyak ditemukan jenis Monolate.

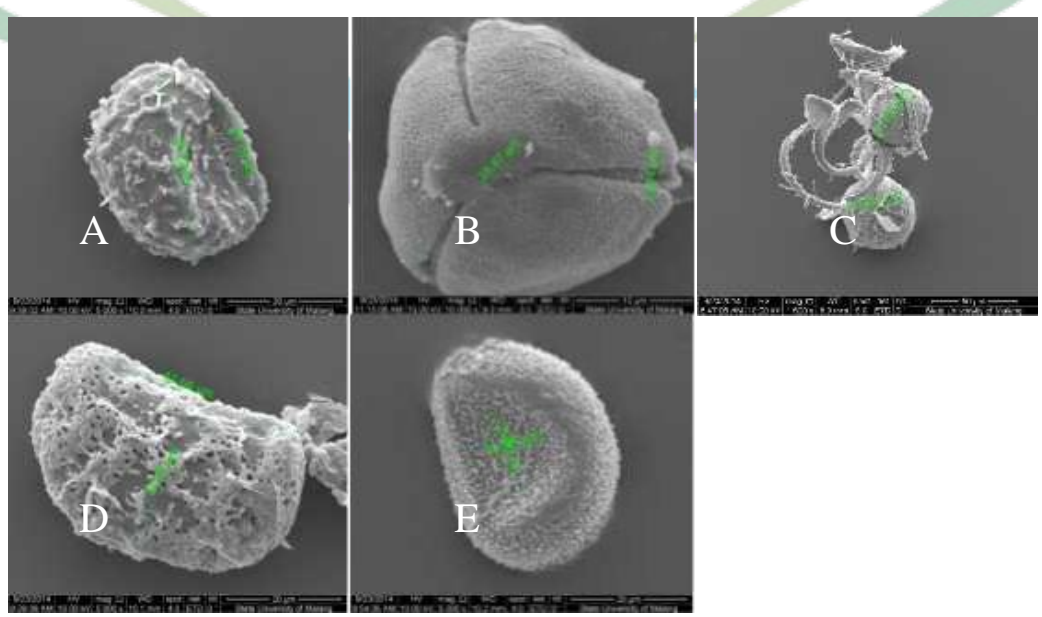

Gambar 2.5.7. Tipe-Tipe Apertura Spora

A. Monolate, B. Trilate, C. Inaperturate, D. Monolate, E. Inaperturate

\footnotetext{
${ }^{62}$ Marpaung et al., "Morfologi Spora Paku Pteridaceae Di Hutan PT . CPI Rumbai Riau."

${ }^{63}$ Sulasmi and Kunci, "Analisis Kekerabatan Spora Tumbuhan Paku Koleksi Herbarium Malangensis."

${ }^{64}$ Marpaung et al., "Morfologi Spora Paku Pteridaceae Di Hutan PT . CPI Rumbai Riau.”
} 


\section{Tipe Ornamentasi}

Ornamentasi (permukaan dinding spora) mempunyai bentuk yang berbeda dan dapat digunakan sebagai karakter kunci pengelompokkan tumbuhan paku. Tipe ornamentasi spora diantaranya yaitu :

a. Tipe Psilate yaitu Ornamentasi eksin dengan ciri seluruh permukaan halus, rata dan licin.

b. Tipe Perforate yaitu memiliki ciri adanya lubang pada permukaan, dan ukuran lubang kurang dari $1 \mu \mathrm{m}$.

c. Tipe Foveolate memiliki permukaan lubang dengan ukuran lubang dapat mencapai lebih dari $1 \mu \mathrm{m}$.

d. Tipe Scabrate yaitu unsur ornamen yang memiliki bentuk isodiametrik dan ukuran $1 \mu \mathrm{m}$.

e. Tipe Gemmate berbentuk isodiametrik dan ukuran lebih dari $1 \mu \mathrm{m}$.

f. Tipe Verrucate memiliki unsur ornamentasi yang memiliki bentuk isodiametrik dan tingginya lebih dari $1 \mu \mathrm{m}$.

g. Tipe Clavate yaitu unsur ornamentasi yang memiliki bentuk seperti tangkai, pada bagian dasarnya menyempit, serta ukuran tinggi lebih dari ukuran lebih lebar. Hal ini sama dengan tipe psilate namun pada bagian apikalnya mengembung.

h. Tipe Echinate memiliki bentuk ornamentasi seperti duri. 
i. Tipe Reticulate memiliki unsur ornamentasi yang berbentuk seperti jaring atau jala. ${ }^{65}$

\section{F. Manfaat Tumbuhan Paku (Pteridophyta)}

Tumbuhan paku pada dasarnya merupakan tumbuhan yang sering di temukan.

Manfaat tumbuhan paku bagi manusia yaitu sebagai berikut :

1. Bahan pangan/sayuran: Marsilia crenata, Pteridium aquilinum

2. Tanaman hias :Platycerium, Adiantum, Asplenium, Sellaginela.

3. Bahan pembersih : Equisetum

4. Bahan obat-obatan : Aspidium filixmas, Lycopodium clavatum

5. Azolla sp. tumbuhan gulma yang berperan sebagai konservasi dalam pengelolahan tanah di lahan yang basah. ${ }^{66}$ Pteridophyta mempunyai komponen yang dapat membentuk vegetasi hutan, menahan limpahan air hujan, mengurangi debit air saat banjir, dan menahan air sebagai sumber kebutuhan. ${ }^{67}$

\footnotetext{
${ }^{65}$ Marpaung et al.

${ }^{66}$ Mantang, Mantiri, and Kolondam, "Identifikasi Tumbuhan Paku Air (Azolla Sp.) Secara Morfologi Dan Molekuler Dengan Menggunakan Gen RbcL."

${ }^{67}$ Miftakhul Jannah, Wahyu Prihanta, and Eko Susetyorini, "Identifikasi Pteridophyta Di Piket Nol Pronojiwo Lumajang Sebagai Sumber Belajar Biologi,” Jurnal Pendidikan Biologi Indonesia 1, no. 1 (2015): 8998, https://doi.org/10.22219/jpbi.v1i1.2306.
} 


\section{DAFTAR PUSTAKA}

Agrawal, Teena, Priyanka Danai, and Monika Yadav. "General Aspects of Pteridophyta - A Review." International Journal of Current Research and Academic Review 5, no. 3 (2017): 80-85. https://doi.org/10.20546/ijcrar.2017.503.012.

Ariyanti, Devi Lia, Windarti, and Efawani. "Types and Destiny of Aquatic in the Parit Belanda Swamp, Rumbai." Jurnal Online Mahasiswa Perikanan Dan Ilmu Kelautan Universitas Riau 17, no. 1-2 (2015).

Ayatusa'adah. "Inventarisassi Tumbuhan Paku (Pteridophyta) Di Kawasan Kampus IAIN Palangka Raya Sebagai Alternatif Media Pembelajaran Materi Klasifikasi Tumbuhan.” Jurnal Pendidikan Sains \& Matematika 5, no. 2 (2017): 50-61.

Azizah. "Karakter Morfologi Paku Sisik Naga (Pyrrosia Piloselloides) Berdasarkan Pada Pohon Inang Berbeda. Universitas Islam Maulana Malik Ibrahim Malang. Jurnal Medika Nusantara." Medika Nusantara, 2016.

Campbell, Neil A \& B. Jane. Biologi Jilid 2 Edisi Ke Delapan. Jakarta: Erlangga, 2008.

EFENDI, MUHAMMAD. "Komposisi Dan Keanekaragaman Flora Di Gunung Pesagi, Sumatera." Jurnal Pros Sem Nas Masy Biodiv Indon 2, no. 2010 (2016): 198-207. https://doi.org/10.13057/psnmbi/m020214.

Elsifa, Armelia, and Harmoko. "Eksplorasi Tumbuhan Paku (Pteridophyta ) Di Stl Ulu Terawas, Musi Rawas, Sumatera Selatan.” Jurnal Tadris Biologi 10, no. 1 (2019): 47-55.

Ajaran Islam. "Gambar Daur Hidup Pteridophyta," 2019. http://islampedia10.blogspot.com/2019/01/embriogenesis-pteridofita.html.

wikipedia. "Gambar Pyrrosia Angustata," 2018. https://id.wikipedia.org/wiki/Pyrrosia.

wikipedia. "Gambar Spesies Azolla Sp.," 2004. https://id.wikipedia.org/wiki/Berkas:Azolla_caroliniana2.jpg.

wikipedia. "Gambar Spesies Cyathea Nilgirensis," 2020. https://en.wikipedia.org/wiki/Cyathea.

Gembong, Tjitoseopomo. Taksonomi Tumbuhan. Yogyakarta: Universitas Gadjah Mada, 1989.

Hutasuhut, Melfa Aisyah, and Husnarika Febriani. "Keanekaragaman PakuPakuan Terestrial Di Kawasan Taman Wisata Alam Sicike-Cike.” Jurnal Biolokus 2, no. 1 (2019): 146-57. 
Imaniar, Relita, and Siti Murdiyah. "Identifikasi Keanekaragaman Tumbuhan Paku Di Kawasan Air Terjun Kapas Biru Kecamatan Pronojiwo Kabupaten Lumajang SertaPemanfaatannya Sebagai Booklet." Jurnal Pendidikan Biologi 6, no. 3 (2017): 337-45.

Jannah, Miftakhul, Wahyu Prihanta, and Eko Susetyorini. "Identifikasi Pteridophyta Di Piket Nol Pronojiwo Lumajang Sebagai Sumber Belajar Biologi." Jurnal Pendidikan Biologi Indonesia 1, no. 1 (2015): 89-98. https://doi.org/10.22219/jpbi.v1i1.2306.

KBBI. "Karakteristik.” 13 Januari $2020 \quad$ (Online), 2020. https://kbbi.web.id/karakteristik.

—. "Morfologi." 16 Januari $2020 \quad$ (Online), 2020. https://kbbi.web.id/morfolog.

Kimball, W Jhon. Biologi Jidil 3 Edisi Kelima. Bogor: Intitut Pertanian Bogor, 1983.

Mantang, W, F. R Mantiri, and B. J Kolondam. "Identifikasi Tumbuhan Paku Air (Azolla Sp.) Secara Morfologi Dan Molekuler Dengan Menggunakan Gen RbcL.” Jurnal Bioslogos 8, no. 2 (2018): 38-44. W Mantang, FR Mantiri, BJ Kolondam - BIOSLOGOS, 2018 - ejournal.unsrat.ac.id.

Mardiyah, Ainol, Hasanuddin, and Eriawati. "Inventarisasi Jenis Paku Di Kawasan Gunung Paroy Kecamatan Lhong Kabupaten Aceh Besar." Prosiding Seminar Nasional Biotik, 2017, 476-85. https://jurnal.arraniry.ac.id/index.php/PBiotik/article/view/2147.

"Karakteristik Warna Sorus Tumbuhan Paku Di Kawasan Gunung Paroy Kecamatan Lhoong Kabupaten Aceh Besar." Prosiding Seminar Nasional Biotik 2016, 2016, 220-28.

Marpaung, Afni Atika, Nery Sofiyanti, Dyah Iriani, Jurusan Biologi, Fakultas Matematika, Pengetahuan Alam, Universitas Riau, Kampus Bina Widya, and Jl H R Soebrantas. "Morfologi Spora Paku Pteridaceae Di Hutan PT . CPI Rumbai Riau." Jurnal Riau Biologia 1, no. September (2016): 149-54.

Muhaimin, Muhamad, Intani Quarta Lailaty, and Imawan Wahyu Hidayat. "Keragaman Tumbuhan Di Kawasan Hutan Lindung Gunung Tanggamus , Lampung Dan Upaya Konservasinya (Plants Diversity in Mount Tanggamus Protected Forest, Lampung and Its Conservation Efforts)." Pros. Sem. Nas. Masy. Biodiv. Indon. 4, no. 2 (2018): 144-50. https://doi.org/10.13057/psnmbi/m040208

Musriadi. "Identifikasi Tumbuhan Paku (Pteridophyta) Sebagai Bahan Ajar Botani Tumbuhan Rendah Di Kawasan Tahura Pocut Meurah Intan Kabupaten Aceh Besar.” Jurnal Pendidikan Sains 05, no. 01 (2017): 22-31. 
Nasution, Jubaidah, Jamilah Nasution, and Emmy Harso Kardhinata. "Inventarisasi Tumbuhan Paku Di Kampus I Universitas Medan Area." Klorofil $1, \quad$ no. $\quad 2 \quad$ (2018): http://jurnal.uinsu.ac.id/index.php/klorofil/article/view/1603/1289.

Nugroho, C, D Larasati, Endah Yuliawati P.S, N Ramadhan, S Savira, T. I Sabrina, A Sedayu, and R. H Ristanto. "Karakteristik Tumbuhan Paku (Pteridophyta) Di Jalur Ciwalen, Taman Nasional Gunung Gede Pangrango, Cisarua, Jawa Barat.” Biodidaktika 13, no. 1 (2018): 28-37. TI Sabrina BIODIDAKTIKA, JURNAL BIOLOGI DAN ..., 2018.

Nurchayati, N. "Identifikasi Profil Karakteristik Morfologi Spora Dan Prothalium Tumbuhan Paku Familia Polypodiaceae.” Bioedukasi 15, no. 2 (2016): 2530.

Nurnasari, Elda, and Djumadi. "Pengaruh Kondisi Ketinggian Tempat Terhadap Produksi Dan Mutu Tembakau Temanggung Elda Nurnasari Dan Djumali." Buletin Tanaman Tembakau, Serat \& Minyak Industri 2, no. 2 (2010): 6717.

Parmadi, E. H., I. Dewiyanti, and S. Karina. "Indeks Nilai Penting Vegetasi Mangrove Di Kawasan Kuala Idi , Kabupaten Aceh Timur.” Jurnal Ilmiah Mahasiswa Kelautan Dan Perikanan Unsyiah 1, no. April (2016): 82-95.

Pranita, Herdina Sukma, Susriyati Mahanal, and Murni Sapta Sari. "KARAKTERISTIK SPORA TUMBUHAN PAKU ASPLENIUM KAWASAN HUTAN RAYA R . SOERJO." Jurnal Pendidikan 2, no. 4 (2017): 454-58.

Pranita, Herdina Sukma, Susriyati Mahanal, Murni Sapta Sari, Inventarisasi Tumbuhan, Paku Kelas, Herdina Sukma Pranita, Susriyati Mahanal, et al. "Inventarisasi Tumbuhan Paku Kelas Filicinae Di Kawasan Watu Ondo Sebagai Media Belajar Mahasiswa 1." Seminar Nas Pendiddikan Dan Saintek, 2016, 733-40.

Quthb, Sayyid. Tafsir Fi Zhilail Qur'an Jilid 4. Beirut: Darusy-Syuruq, 1992.

Rahayuningsih, Margareta, Mualimaturrochmah Mualimaturrochmah, and Amin Retnoningsih. "Species Richness of Pteridophyta in Mount Ungaran." KnE Social Sciences $2019 \quad$ (2019): https://doi.org/10.18502/kss.v3i18.4730.

ROZIATY, EFRI, PUTRI AGUSTINA, and RIZKA NURFITRIANTI. "Pterydophyta Epifit Kawasan Wisata Air Terjun Jumog Ngargoyoso Karanganyar Jawa Tengah.” Bioedukasi: Jurnal Pendidikan Biologi 9, no. 2 (2016): 76. https://doi.org/10.20961/bioedukasi-uns.v9i2.8586.

Sadono, Agus. "Keanekaragaman Jenis ( Species ) Tumbuhan Paku ( Pteridophyta ) Di Area Kampus Upr.” Jurnal Hutan Tropika XIII, no. 2 (2018): 63-76. 
Schuettpelz, Eric, Harald Schneider, Alan R. Smith, Peter Hovenkamp, Jefferson Prado, Germinal Rouhan, Alexandre Salino, et al. "A Community-Derived Classification for Extant Lycophytes and Ferns." Journal of Systematics and Evolution 54, no. 6 (2016): 563-603. https://doi.org/10.1111/jse.12229.

Seno, Akbar Aji, Vidhy Setyantoro, and Budhi Utami. "Profil Karakteristik Bentuk Sorus Tumbuhan Paku Di Kawasan Wisata Air Terjun Ironggolo Kabupaten Kediri." Prosiding Seminar Nasional IX Biologi FKIP UNS, 2012, 460-67. http://jurnal.fkip.uns.ac.id/index.php/prosbio/article/view/1127.

Sukara, Endang, and Imran SL Tobing. "Industri Berbasis Keanekaragaman Hayati, Masa Depan Indonesia." Vis Vatalis 1, no. 2 (2008): 1-12.

Sulasmi, Eko Sri, and Kata Kunci. "Analisis Kekerabatan Spora Tumbuhan Paku Koleksi Herbarium Malangensis." Jurnal Biologi: Prosding Seminar Nasional Hayati V, 2017, 162-69.

Tjitoseopomo, Gembong. Taksonomi Tumbuhan. Yogyakarta: Universitas Gadjah Mada, 1989.

Widiyanto, Joko, Ayu Wulandari, and Maeheny Lukitasari. "Identifikasi Keragaman Paku Di Kawasan Wisata Mojosemi Forest Park." Prosding Seminar Nasional SIMBIOSIS II 2, no. September (2017): 434-42.

Yusuf, M Asep Maulana. "Pteridophyta Di Kawasan Cagar Alam,” 2009.

Zulfia, Firda Ama, Indah Syafinatu Zafi, Kuni Mawaddah, Leviana Erinda, and Eko Sri Sulasmi. "Keanekaragaman Spora Pteridophyta Sekitar Kampus Sebagai Media Pembelajaran Realia Mahasiswa Calon Guru Biologi Universitas Negeri Malang Abstrak." Prosding Semnas Hayati JV, 2016, 193-98. 